\title{
Sediment phosphorus speciation and mobility under dynamic redox conditions
}

\author{
Chris T. Parsons ${ }^{1}$, Fereidoun Rezanezhad ${ }^{1}$, David W. O'Connell ${ }^{1,2}$, and Philippe Van Cappellen ${ }^{1}$ \\ ${ }^{1}$ Ecohydrology Research Group and The Water Institute, University of Waterloo, 200 University Avenue West, \\ Waterloo, Ontario, Canada \\ ${ }^{2}$ Department of Civil, Structural and Environmental Engineering, Trinity College Dublin, College Green, \\ Museum Building, Dublin, Ireland \\ Correspondence to: Chris T. Parsons (chris.parsons@uwaterloo.ca)
}

Received: 9 December 2016 - Discussion started: 9 January 2017

Revised: 5 May 2017 - Accepted: 23 June 2017 - Published: 27 July 2017

\begin{abstract}
Anthropogenic nutrient enrichment has caused phosphorus $(\mathrm{P})$ accumulation in many freshwater sediments, raising concerns that internal loading from legacy $\mathrm{P}$ may delay the recovery of aquatic ecosystems suffering from eutrophication. Benthic recycling of $\mathrm{P}$ strongly depends on the redox regime within surficial sediment. In many shallow environments, redox conditions tend to be highly dynamic as a result of, among others, bioturbation by macrofauna, root activity, sediment resuspension and seasonal variations in bottom-water oxygen $\left(\mathrm{O}_{2}\right)$ concentrations. To gain insight into the mobility and biogeochemistry of $\mathrm{P}$ under fluctuating redox conditions, a suspension of sediment from a hypereutrophic freshwater marsh was exposed to alternating 7-day periods of purging with air and nitrogen gas $\left(\mathrm{N}_{2}\right)$, for a total duration of 74 days, in a bioreactor system. We present comprehensive data time series of bulk aqueous- and solidphase chemistry, solid-phase phosphorus speciation and hydrolytic enzyme activities demonstrating the mass balanced redistribution of $\mathrm{P}$ in sediment during redox cycling. Aqueous phosphate concentrations remained low $(\sim 2.5 \mu \mathrm{M})$ under oxic conditions due to sorption to iron(III) oxyhydroxides. During anoxic periods, once nitrate was depleted, the reductive dissolution of iron(III) oxyhydroxides released P. However, only $4.5 \%$ of the released $\mathrm{P}$ accumulated in solution while the rest was redistributed between the $\mathrm{MgCl}_{2}$ and $\mathrm{NaHCO}_{3}$ extractable fractions of the solid phase. Thus, under the short redox fluctuations imposed in the experiments, $\mathrm{P}$ remobilization to the aqueous phase remained relatively limited. Orthophosphate predominated at all times during the experiment in both the solid and aqueous phase. Com-
\end{abstract}

bined $\mathrm{P}$ monoesters and diesters accounted for between 9 and $16 \%$ of sediment particulate P. Phosphatase activities up to $2.4 \mathrm{mmol} \mathrm{h}^{-1} \mathrm{~kg}^{-1}$ indicated the potential for rapid mineralization of organic $\mathrm{P}\left(\mathrm{P}_{\mathrm{o}}\right)$, in particular during periods of aeration when the activity of phosphomonoesterases was $37 \%$ higher than under $\mathrm{N}_{2}$ sparging. The results emphasize that the magnitude and timing of internal $\mathrm{P}$ loading during periods of anoxia are dependent on both $\mathrm{P}$ redistribution within sediments and bottom-water nitrate concentrations.

\section{Introduction}

It is widely recognized that accelerated eutrophication of freshwater aquatic environments is caused primarily by anthropogenic increases to dissolved phosphorus $(\mathrm{P})$ concentrations in surface water (Smith and Schindler, 2009). Rapid cultural eutrophication of oligo or mesotrophic lacustrine and palustrine systems is often attributed to increased external $\mathrm{P}$ loadings originating in agricultural run-off or waste water treatment plant (WWTP) effluent. The resultant excessive algal growth negatively impacts aquatic ecosystems and economic activity (Pretty et al., 2003) and increases the risk of infectious diseases (Chun et al., 2013). Strategies to mitigate eutrophication have aimed to reduce point source and diffuse external phosphorus loadings by instituting agricultural best-management practices in the surrounding watershed (McLaughlin and Pike, 2014; Sharpley et al., 1994), limiting $\mathrm{P}$ inputs to domestic waste water (Corazza and Tironi, 2011) and upgrading WWTPs (Mallin et al., 2005). 
However, internal loading of $\mathrm{P}$, from sediments to surface water, remains poorly quantified in many systems and is often the largest source of error in hydrodynamic and ecological phosphorus models (Kim et al., 2013). Early diagenesis and mineralogical removal of labile autochthonous organic phosphorus $\left(\mathrm{P}_{\mathrm{o}}\right)$ from solution is a complex process and is poorly understood in highly dynamic systems despite exerting a strong influence on the magnitude and timing of internal $\mathrm{P}$ loading. This is particularly true in shallow lakes and wetlands due to the high ratio of sediment surface area to water column depth (Søndergaard et al., 2003).

As policy and infrastructure improvements continue in order to mitigate external $\mathrm{P}$ inputs to aquatic systems, the relative importance of internal $P$ loads from legacy $P$ in sediments to overall $\mathrm{P}$ budgets in eutrophic systems is likely to increase (Reddy et al., 2011).

It has been widely demonstrated through laboratory and field investigations, particularly in seasonally anoxic lakes, that sustained anoxic conditions induced by water column stratification typically result in greater P mobility and correspondingly higher water column P concentrations (Krom and Berner, 1981; Einsele, 1936; Hongve, 1997; Katsev et al., 2006; Mortimer, 1941, 1971; Penn et al., 2000). The microbially mediated reductive dissolution of iron(III) oxyhydroxides or iron(III) phosphate during sustained periods of anoxia at the sediment-water interface (SWI) has long been considered the main mechanism responsible for $\mathrm{P}$ release under anoxic conditions (Bonneville et al., 2004; Hyacinthe and Van Cappellen, 2004).

More recently, considerable microbial polyphosphate accumulation and release in response to alternating oxicanoxic conditions at the SWI in lacustrine environments has also been shown to occur (Gächter et al., 1988; Gächter and Meyer, 1993; Hupfer et al., 2007; Sannigrahi and Ingall, 2005). In some cases this accumulation of polyphosphate by the microbial community may account for $10 \%$ of total phosphorus (Hupfer et al., 2007).

However, redox conditions in shallow, heavily bioturbated sediments are more spatially and temporally variable than in seasonally anoxic lakes (Aller, 1994; Gorham and Boyce, 1989), resulting in short-term redox oscillations even with continuous oxia at the SWI.

Additionally, the coupled biogeochemical cycles of other redox sensitive elements such as sulfur and carbon have been shown to play important and complex roles in phosphorus mobility (Gächter and Müller, 2003; Joshi et al., 2015; O'Connell et al., 2015). For example, high bottom-water sulfate concentrations have been shown to increase aqueous $\mathrm{P}$ in sediments by decreasing the permanent mineralogical removal of $\mathrm{P}$ within vivianite $\left[\mathrm{Fe}_{3}\left(\mathrm{PO}_{4}\right)_{2(\mathrm{~s})}\right]$ and by decreasing the abundance of iron(III) oxyhydroxides near to the SWI (Caraco et al., 1989). This is due to the scavenging of iron during the formation of iron sulfide minerals within sediment during diagenesis (Gächter and Müller, 2003). Carbon cycling also exerts considerable control over phospho- rus mobility within sediment. The stoichiometry of freshly deposited organic matter $(\mathrm{OM})$ in eutrophic water bodies approaches that of primary production, i.e. $\sim \mathrm{C}_{106}: \mathrm{N}_{16}: \mathrm{P}$ (Berner, 1977). Appreciable P may therefore be released to the aqueous phase when organic carbon is mineralized during microbial respiration of oxygen, nitrate, ferric iron or sulfate. In addition to driving $\mathrm{N}, \mathrm{Fe}$ and $\mathrm{S}$ cycling, mineralization of organic carbon and concomitant $\mathrm{P}$ release has, in some places, been shown to be the primary mechanism controlling phosphorus mobility at the SWI (Joshi et al., 2015).

Core incubations and in situ flux chambers frequently examine the effects of anoxia on P mobility from sediments but the effects of repetitive redox oscillations are rarely investigated in a controlled setting (Frohne et al., 2011; Matisoff et al., 2016; Nürnberg, 1988; Thompson et al., 2006). Consequently, the cumulative and reversible effects of oxic-anoxic cycling on $\mathrm{P}$ distribution, speciation and mobility within sediments are poorly understood.

The aim of this study is to elucidate the microbial and geochemical mechanisms of in-sediment phosphorus cycling and release associated with commonly occurring short redox fluctuations (days) in surficial sediments in shallow eutrophic environments. Particularly, we aimed to (1) quantify the redistribution of $\mathrm{P}$ between aqueous and mineral sediment pools during fluctuating redox conditions; (2) determine whether the activity of hydrolytic phosphatase enzymes acting on $\mathrm{P}_{\mathrm{o}}$ were influenced by redox conditions; (3) assess whether the proportions of orthophosphate, $P_{o}$, and polyphosphate varied systematically with redox conditions; and (4) ascertain whether P mobilization/immobilization mechanisms were reversible or cumulative.

We conducted controlled bioreactor experiments using sediment suspensions, designed to reproduce cyclic redox conditions analogous to those occurring in nature (Aller, 1994, 2004). A combination of aqueous chemistry, sediment sequential extractions (Ruttenberg, 1992), ${ }^{31} \mathrm{P}$ NMR spectroscopy (Cade-Menun, 2005) and extra-cellular enzyme assays (Deng et al., 2013) were used to produce a comprehensive dataset describing bulk chemistry, microbial and mineralogical controls on P mobility and speciation during redox oscillations.

\section{Methods}

\subsection{Field site and sampling}

Surface sediment $(0-12 \mathrm{~cm})$, sediment cores $(34 \mathrm{~cm}$ long, $10 \mathrm{~cm}$ diameter), overlying water and green filamentous algae (GFA) were collected on 5 September 2013 from West Pond in Cootes Paradise Marsh $\left(43.26979^{\circ} \mathrm{N}, 79.92899^{\circ} \mathrm{W}\right)$ following established guidelines (US EPA, September 2009). Cootes Paradise is a hypereutrophic, coastal freshwater marsh, which drains into Lake Ontario via Hamilton Harbour (see Fig. 1a-c). The marsh system suffered severe degrada- 


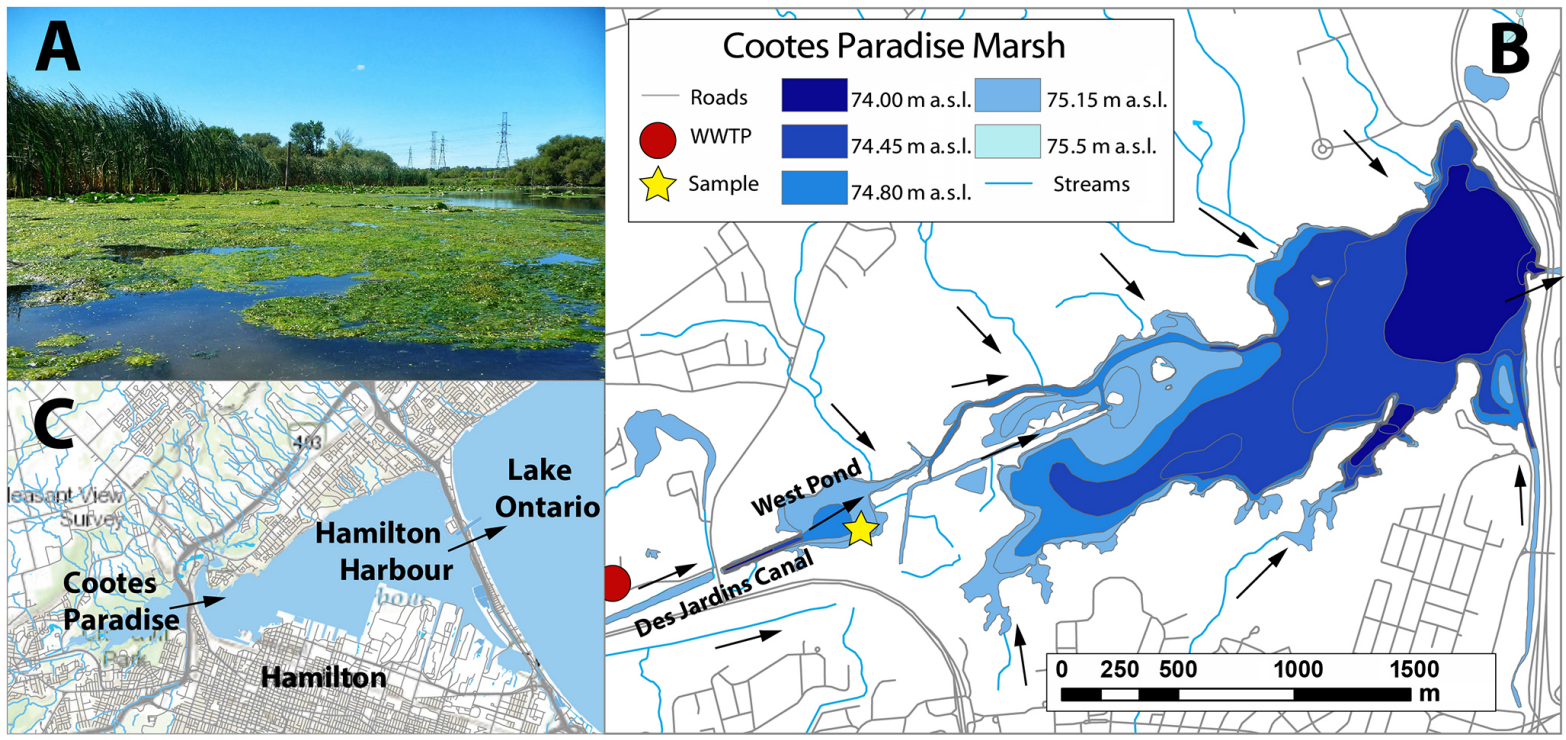

Figure 1. (a) Photograph of the sampling location taken on the day of sampling illustrating the abundance of green filamentous algae. (b) Map of Cootes Paradise and West Pond showing the sampling location, local hydrological network and the King Street Waste Water Treatment plant in Dundas, Hamilton. Colour represents area covered by surface water at different water levels (m.s.l. is metres above sea level). (c) Overview map showing the hydrological connection between Cootes Paradise, Hamilton Harbour and Lake Ontario.

tion due to rapid urbanization, population growth and nutrient loadings in the 20th century (Chow-Fraser et al., 1998). West Pond in particular received extremely high external P loads from the King Street (Dundas) WWTP for several decades prior to the installation of sand filters in 1987 (Painter et al., 1991). The addition of sand filters, and other improvements, decreased P loadings from the WWTP from $45 \mathrm{~kg} \mathrm{Pday}^{-1}$ in the early 1970s (Semkin et al., 1976) to $4.5 \mathrm{~kg} \mathrm{Pday}^{-1}$ in the 1980s (Chow-Fraser et al., 1998) and $2.59 \mathrm{~kg} \mathrm{Pday}^{-1}$ in 2011 (Routledge, 2012). However, high external $\mathrm{P}$ loads resulted in accumulation of legacy $\mathrm{P}$ in West Pond sediments with total phosphorus concentrations reaching $200 \mu \mathrm{mol} \mathrm{g}^{-1}$ by the 1980 s (Theysmeyer et al., 1999). Consequently, dredging was conducted in 1999 in an attempt to remediate the areas most affected by growth of green filamentous algae (Bowman and Theysmeyer, 2014).

Despite these restoration efforts and decreases to the external $\mathrm{P}$ load, pervasive growth of GFA during the summer persists in parts of Cootes Paradise (Fig. 1a). Cyanobacteria are not commonly observed at this location, potentially due to the high $\mathrm{N}: \mathrm{P}$ ratios often associated with WWTP which utilize tertiary P removal treatment (Conley et al., 2009; Stumm and Morgan, 1996).

\subsection{Sediment characterization}

Sediment cores were sliced every $3 \mathrm{~cm}$, homogenized and characterized with bulk sediment samples prior to bioreactor experiments. Organic carbon and carbonate depth profiles were determined by thermogravimetric analysis (TGAQ500, TA Instruments Q500) (Pallasser et al., 2013). Water content and bulk density $\left(\rho_{\mathrm{b}}\right)$ of the sliced sediment core were determined gravimetrically after oven drying (Gardner, 1986). Identification and quantification of crystalline mineralogy was determined by powder X-ray diffraction (XRD) (Empyrean Diffractometer and Highscore Plus software Ver. 3.0e PANalytical). The density of benthic macroinvertebrates was also quantified after sieving two additional cores $(7.5 \mathrm{~cm}$ diameter, $18 \mathrm{~cm}$ deep) through $500 \mu \mathrm{m}$ mesh.

\subsection{Bioreactor experiment and redox oscillation procedure}

An initial concentrated sediment suspension of approximately $500 \mathrm{~g} \mathrm{~L}^{-1}$ (dry weight equivalent) was prepared from freshly sampled sediment $(0-12 \mathrm{~cm})$ and filtered overlying water $(<0.45 \mu \mathrm{m})$. Surface water was used, rather than distilled water, to provide background ionic strength and avoid osmotic shock to the microbial community. The concentrated suspension was stirred vigorously for $5 \mathrm{~min}$ then passed through a $<500 \mu \mathrm{m}$ stainless steel sieve to remove larger solid organic material and macro-invertebrates. This procedure was repeated until a homogeneous suspension was achieved. The dry weight was then re-determined, and the sieved solution was diluted with filtered surface water to a final concentration of $247 \pm 2 \mathrm{~g} \mathrm{~L}^{-1}$. The resulting suspension was transferred to a bioreactor system (Applikon Biotechnology) after Thompson et al. (2006) and Parsons et al. (2013). In addition to affording precise temperature control and continuous logging of temperature, redox potential $\left(E_{h}\right)$ and $\mathrm{pH}$, the system offers significant advancements over previous designs (Thompson 2006; Guo, 2007; Parsons, 2013). 
The $E_{h}, \mathrm{pH}$ and dissolved oxygen (DO) were measured using a combined autoclavable Mettler Toledo InPro 3253i/SG open-junction electrode and an AppliSens low drift polarographic sensor. The InPro electrode system, using a common reference electrode, was chosen to help avoid potential interference between two electrodes in close proximity. A multiparameter transmitter was used to display current $\mathrm{pH}, E_{h}$ and temperature to automatically temperature-correct $\mathrm{pH}$ values and to adjust measured $E_{h}$ to the standard hydrogen electrode (SHE). DO was calibrated using $100 \%$ saturation in air (approximately $0.2905 \mathrm{~atm}$ ) and $0 \%$ saturation in $\mathrm{N}_{2}$ at constant sparging of $30 \mathrm{~mL} \mathrm{~min}^{-1}$

The suspension was stirred continuously and sparged with $30 \mathrm{~mL} \mathrm{~min}^{-1}$ air for 11 days to equilibrate prior to the redox oscillation procedure. During the 11-day oxic equilibration period, $\mathrm{CO}_{2}$ emissions were monitored in the reactor exhaust gas using an IR sensor (Applikon Biotechnology).

Subsequently, redox potential $\left(E_{h}\right)$ variation was induced by the modulation of sparging gases $\left(30 \mathrm{~mL} \mathrm{~min}^{-1}\right)$ between $\mathrm{N}_{2}: \mathrm{CO}_{2}$ and $\mathrm{O}_{2}: \mathrm{N}_{2}: \mathrm{CO}_{2}$. The suspension was subjected to five cycles of anoxia (7 days) and oxia (7 days) at constant temperature $\left(25^{\circ} \mathrm{C}\right)$ in the dark, while recording $E_{h}$, $\mathrm{pH}, \mathrm{DO}$ and temperature data. The suspension was sampled on days 1, 3, 5 and 7 of each half-cycle. To separate solid and aqueous components from the sediment suspension, syringe-extracted samples $(15 \mathrm{~mL})$ were centrifuged at $5000 \mathrm{rpm}$ for $20 \mathrm{~min}$ and the supernatant filtered through $0.45 \mu \mathrm{m}$ polypropylene membrane filters prior to all aqueous analysis. For samples taken during anoxic half-cycles, centrifugation, filtering and subsampling were performed in an anoxic glove box $\left(\mathrm{N}_{2}: \mathrm{H}_{2}\right.$ 97:3\%, $\left.\mathrm{O}_{2}<1 \mathrm{ppmv}\right)$. Time periods were chosen to be representative of short temporal fluctuations to redox conditions experienced by surficial sediments (Aller, 1994; Nikolausz et al., 2008; Parsons et al., 2013). Similarly, the temperature and dark conditions were chosen to reflect those measured in surficial sediment during summer months at the field site. Summer conditions were chosen as this is when maximum bioturbation, microbial activity and OM input are expected within the sediment. Similar, long-running batch reactor experiments using soil or sediment have previously experienced a slowdown of metabolic processes due to depletion of labile organic carbon (Parsons et al., 2013). Therefore, gaseous carbon and nitrogen losses from the reactor were balanced by the addition of $3 \mathrm{~g}$ of freeze-dried and ground GFA to the suspension at the onset of each anoxic cycle. The amount of algae added was determined based on $\mathrm{CO}_{2}$ production from the reactor during the initial 11-day oxic period.

\subsection{Aqueous-phase methods}

All reagents used were of analytical grade from Fluka, Sigma-Aldrich or Merck unless stated otherwise and were prepared with $18.2 \mathrm{M} \Omega \mathrm{cm}^{-1}$ water (Millipore). Total dissolved $\mathrm{Na}$ (70), $\mathrm{K}(100), \mathrm{Ca}(20), \mathrm{Mg}(0.5), \mathrm{Mn}(1), \mathrm{Fe}(3)$,
$\mathrm{Al}(100), \mathrm{P}$ (2), Si (15) and S (15) concentrations (MDL in $\mu \mathrm{g} \mathrm{L}^{-1}$, in parentheses) were determined by ICP-OES (Thermo Scientific iCAP 6300) after filtration $(<0.45 \mu \mathrm{m})$ and acidification with $\mathrm{HNO}_{3}$ to $<\mathrm{pH}$ 2. Matrix-matched standards were used for all calibrations and NIST validated multi-elemental solutions were used as controls. SRP concentrations were determined by the molybdenum blue/ascorbic acid method on a LaChat QuickChem 8500 flow injection analyzer system (4500-P E: Phosphorus by Ascorbic Acid, National Water Quality Monitoring Council, 1992; Murphy and Riley, 1962) (MDL $1.2 \mu \mathrm{g} \mathrm{PL}^{-1}$ ). DOC was determined using a Shimadzu TOC-LCPH/CPN analyzer (Shimadzu) following $\mathrm{HCl}$ addition $(<\mathrm{pH} 2)$ to degas dissolved inorganic carbon (MDL $71 \mu \mathrm{g} \mathrm{CL}^{-1}$ ).

Chloride, nitrate, nitrite and sulfate concentrations were measured by ion chromatography using a Dionex ICS 5000 equipped with a capillary IonPac ${ }^{\circledR}$ AS18 column. Aqueous sulfide was stabilized with $20 \mu \mathrm{L} 1 \%$ zinc acetate per $\mathrm{mL}$ (Pomeroy, 1954) after filtering and determined by the Cline method (Cline, 1969) (MDL $0.5 \mu \mathrm{M}) . \mathrm{Fe}_{(\mathrm{aq})}^{2+}$ was determined by the ferrozine method immediately after filtering (Stookey, 1970; Viollier et al., 2000) (MDL 3.8 $\mu \mathrm{M}$ ). All aqueous analyses were conducted in triplicate. The precision and accuracy for all techniques was $<5 \mathrm{RSD} \%$ and $\pm 10 \%$ with respect to certified reference materials (where commercially available).

\subsection{Solid-phase methods: phosphorus and iron speciation}

Phosphorus partitioning within the solid phase in the reactor experiment was evaluated over a time series by both sequential extractions, using a modification (Baldwin, 1996) of the SEDEX extraction scheme (Ruttenberg, 1992) and solution ${ }^{31}$ P NMR spectroscopy (Cade-Menun, 2005). The two approaches are complementary; ${ }^{31} \mathrm{P}$ NMR spectroscopy provides information on the molecular speciation of phosphorus, while sequential extraction provides information on the association of the $\mathrm{P}$ species with operationally defined solid-phase fractions. Therefore the combination of these two methods reveals redistribution of $\mathrm{P}$ within the solid phase over time during oxic-anoxic transitions.

The original SEDEX extraction scheme quantifies five different $\mathrm{P}$ reservoirs within sediment by consecutively solubilizing progressively more recalcitrant phases by using extracts of increasing severity. The reaction mechanisms associated with each extraction step are discussed in detail within Ruttenberg (1992). A modification of the SEDEX extraction scheme proposed by Baldwin (1996), used here, incorporates an additional $16 \mathrm{~h}, 1 \mathrm{M} \mathrm{NaHCO}_{3}$ step $\left(\mathrm{P}_{\mathrm{Hum}}\right)$ after the $\mathrm{P}_{\mathrm{Ex}}$ step, to differentiate $\mathrm{OM}$-associated $\mathrm{P}$ which may otherwise be co-extracted during the $\mathrm{P}_{\mathrm{Fe}}$ step. The $\mathrm{pH}$ of the $\mathrm{NaHCO}_{3}$ extraction step was adjusted to 7.6 to minimize dissolution of carbonates prior to the $\mathrm{P}_{\mathrm{CFA}}$ extraction step. A total of 15 samples between days 11 and 74 of the reactor experiment were analysed in duplicate by sequential extraction. A sum- 
Table 1. Summary of the modified SEDEX sequential extraction protocol used on solid samples taken over a time series during the reactor experiment. Results of this extraction are shown in Fig. 4.

\begin{tabular}{|c|c|c|c|}
\hline Step & Extractant & Conditions & Target phase \\
\hline $1 \mathrm{a}$ & $1 \mathrm{M} \mathrm{MgCl}_{2}$ & $\mathrm{pH} 8$ for $2 \mathrm{~h}$ at $25^{\circ} \mathrm{C}$ & Exchangeable or loosely \\
\hline $1 b$ & $1 \mathrm{M} \mathrm{MgCl}_{2}$ & $\mathrm{pH} 8$ for $2 \mathrm{~h}$ at $25^{\circ} \mathrm{C}$ & sorbed $\mathrm{P}\left(\mathrm{P}_{\mathrm{Ex}}\right)$ \\
\hline $1 \mathrm{c}$ & $18.2 \mathrm{M} \Omega \mathrm{cm}^{-1} \mathrm{H}_{2} \mathrm{O}$ & $2 \mathrm{~h}$ at $25^{\circ} \mathrm{C}$ & \\
\hline $2 \mathrm{a}$ & $1 \mathrm{M} \mathrm{NaHCO}_{3}$ & $\mathrm{pH} 7.6$ for $16 \mathrm{~h}$ at $25^{\circ} \mathrm{C}$ & Organic associated $\mathrm{P}$ \\
\hline $2 b$ & $1 \mathrm{M} \mathrm{NaHCO}_{3}$ & $\mathrm{pH} 7.6$ for $2 \mathrm{~h}$ at $25^{\circ} \mathrm{C}$ & $\left(\mathrm{P}_{\text {Hum }}\right)$ \\
\hline $2 \mathrm{c}$ & $1 \mathrm{M} \mathrm{NaHCO}_{3}$ & $\mathrm{pH} 7.6$ for $2 \mathrm{~h}$ at $25^{\circ} \mathrm{C}$ & \\
\hline $2 d$ & $1 \mathrm{M} \mathrm{NaHCO}_{3}$ & $\mathrm{pH} 7.6$ for $2 \mathrm{~h}$ at $25^{\circ} \mathrm{C}$ & \\
\hline $2 \mathrm{e}$ & $1 \mathrm{M} \mathrm{MgCl}_{2}$ & $\mathrm{pH} 8$ for $2 \mathrm{~h}$ at $25^{\circ} \mathrm{C}$ & \\
\hline $3 \mathrm{a}$ & $\begin{array}{l}0.3 \mathrm{M} \mathrm{Na}_{3} \text { citrate with } 1 \mathrm{M} \mathrm{NaHCO} \\
\text { with } 1.125 \mathrm{~g} \text { of } \mathrm{Na} \text { dithionite }(\mathrm{CDB})\end{array}$ & $\mathrm{pH} 7.6$ for $8 \mathrm{~h}$ at $25^{\circ} \mathrm{C}$ & Fe-bound $\mathrm{P}\left(\mathrm{P}_{\mathrm{Fe}}\right)$ \\
\hline $3 b$ & $\mathrm{CDB}$ & $\mathrm{pH} 7.6$ for $2 \mathrm{~h}$ at $25^{\circ} \mathrm{C}$ & \\
\hline $3 c$ & $1 \mathrm{M} \mathrm{MgCl}_{2}$ & $\mathrm{pH} 8$ for $2 \mathrm{~h}$ at $25^{\circ} \mathrm{C}$ & \\
\hline $4 \mathrm{a}$ & $1 \mathrm{M} \mathrm{Na}$ acetate with acetic acid & $\mathrm{pH} 4$ for $6 \mathrm{~h}$ at $25^{\circ} \mathrm{C}$ & Authigenic carbonate fluorapatite \\
\hline $4 \mathrm{~b}$ & $1 \mathrm{M} \mathrm{Na}$ acetate with acetic acid & $\mathrm{pH} 4$ for $2 \mathrm{~h}$ at $25^{\circ} \mathrm{C}$ & plus biogenic apatite plus \\
\hline $4 c$ & $1 \mathrm{M} \mathrm{MgCl}_{2}$ & $\mathrm{pH} 8$ for $2 \mathrm{~h}$ at $25^{\circ} \mathrm{C}$ & $\mathrm{CaCO}_{3}$-bound $\mathrm{P}\left(\mathrm{P}_{\mathrm{CFA}}\right)$ \\
\hline 5 & $1 \mathrm{M} \mathrm{HCl}$ & $16 \mathrm{~h}$ at $25^{\circ} \mathrm{C}$ & $\begin{array}{l}\text { Detrital apatite plus other } \\
\text { inorganic } \mathrm{P}\left(\mathrm{P}_{\text {Detri }}\right)\end{array}$ \\
\hline 6 & $1 \mathrm{M} \mathrm{HCl}$ & $16 \mathrm{~h}$ after ashing at $550^{\circ} \mathrm{C}$ at $25^{\circ} \mathrm{C}$ & Residual/organic $\mathrm{P}\left(\mathrm{P}_{\text {Resi }}\right)$ \\
\hline
\end{tabular}

mary of the full sequential extraction method used, including target phases, reactants, $\mathrm{pH}$, temperature and reaction times is provided in Table 1.

Changes to iron speciation were also evaluated through a time series during the experiment. To account for surfacesorbed or freshly precipitated $\mathrm{Fe}$, total $\mathrm{Fe}^{2+}$ production during anoxic half-cycles was estimated by a partial extraction $(1 \mathrm{~h}, 0.5 \mathrm{~N} \mathrm{HCl})$ on sampled suspensions. $\mathrm{Fe}^{2+} / \mathrm{Fe}^{3+}$ ratios were determined in extracts using a modification of the ferrozine method (Stookey, 1970; Viollier et al., 2000). Additionally, a thermodynamic model was implemented in PHREEQC (Parkhurst et al., 1999) to assess the saturation index (SI) of various minerals over time during the reactor experiment using measured $\mathrm{pH}$, temperature, $E_{h}$ and concentration data.

\subsection{NaOH-EDTA extraction and solution ${ }^{31}$ P NMR spectroscopy}

Molecular changes to $\mathrm{P}$ speciation were evaluated over a time series by solution ${ }^{31} \mathrm{P}$ NMR. Phosphorus was extracted directly from suspension samples $(\sim 2 \mathrm{~g}$ dry weight equivalent) prior to ${ }^{31} \mathrm{P}$ NMR analysis. The method used has been shown to allow quantitative analyses of $\mathrm{P}_{\mathrm{o}}$ (monoesters and diesters), polyphosphates and orthophosphates (Amirbahman et al., 2013; Cade-Menun et al., 2006; Cade-Menun and Preston, 1996; Reitzel et al., 2007; Turner et al., 2003b). Briefly, samples were extracted in $25 \mathrm{~mL}$ of $0.25 \mathrm{M}(\mathrm{NaOH})$ and $\mathrm{Na}_{2}$ EDTA $(0.05 \mathrm{M})$ at ambient laboratory temperature $\left(\sim 22{ }^{\circ} \mathrm{C}\right.$ ) for $4 \mathrm{~h}$. Subsequently, the tubes were centrifuged ( $2300 \mathrm{~g}$ for $20 \mathrm{~min}$ ), and the supernatant extracted via syringe and then neutralized with $2 \mathrm{M} \mathrm{HCl}$ to a $\mathrm{pH}$ of 7 to avoid the breakdown of polyphosphates during freeze-drying (Cade-Menun et al., 2006). This solution was then filtered to $<0.45 \mu \mathrm{m}$. Prior to freeze-drying $1 \mathrm{~mL}$ aliquots of each sample were diluted and analysed by ICP-OES spectroscopy for $\mathrm{Al}, \mathrm{Ca}, \mathrm{Fe}, \mathrm{Mg}, \mathrm{Mn}$ and $\mathrm{P}$. The remaining extracts were frozen at $-80^{\circ} \mathrm{C}$ and freeze-dried for $48 \mathrm{~h}$. The freezedried extracts were re-dissolved in $1.0 \mathrm{~mL} \mathrm{D}_{2} \mathrm{O}, 0.6 \mathrm{~mL} 10 \mathrm{M}$ $\mathrm{NaOH}$ and $0.6 \mathrm{~mL}$ of the $\mathrm{NaOH}-$ EDTA extractant solution and were allowed to stand for $10 \mathrm{~min}$ with occasional vortexing. Samples were centrifuged for $20 \mathrm{~min}$ at $2300 \mathrm{~g}$, transferred to $10 \mathrm{~mm}$ NMR tubes and stored at $4{ }^{\circ} \mathrm{C}$ before analysis within $12 \mathrm{~h}$.

Solution ${ }^{31} \mathrm{P}$ NMR spectra were obtained using a $600 \mathrm{MHz}$ spectrometer equipped with a $10 \mathrm{~mm}$ broadband probe. The NMR parameters were $90^{\circ}$ pulse, $0.68 \mathrm{~s}$ acquisition time, $4.32 \mathrm{~s}$ pulse delay, $12 \mathrm{~Hz}$ spinning, $20^{\circ} \mathrm{C}$ and 2200 to 2900 scans (3-4 h) (Cade-Menun et al., 2010). Phosphorus compounds were identified by their chemical shifts relative to an external orthophosphoric acid standard, with the orthophosphate peak in all spectra standardized to $6 \mathrm{ppm}$. Peak areas were calculated by integration on spectra processed with 10 and $7 \mathrm{~Hz}$ line broadening, using NUTS software (Acorn NMR, Livermore CA, 2000 edition). Peak assignments were grouped into compounds or groups of specific compound classes when direct identifications could not be made (CadeMenun, 2005). 

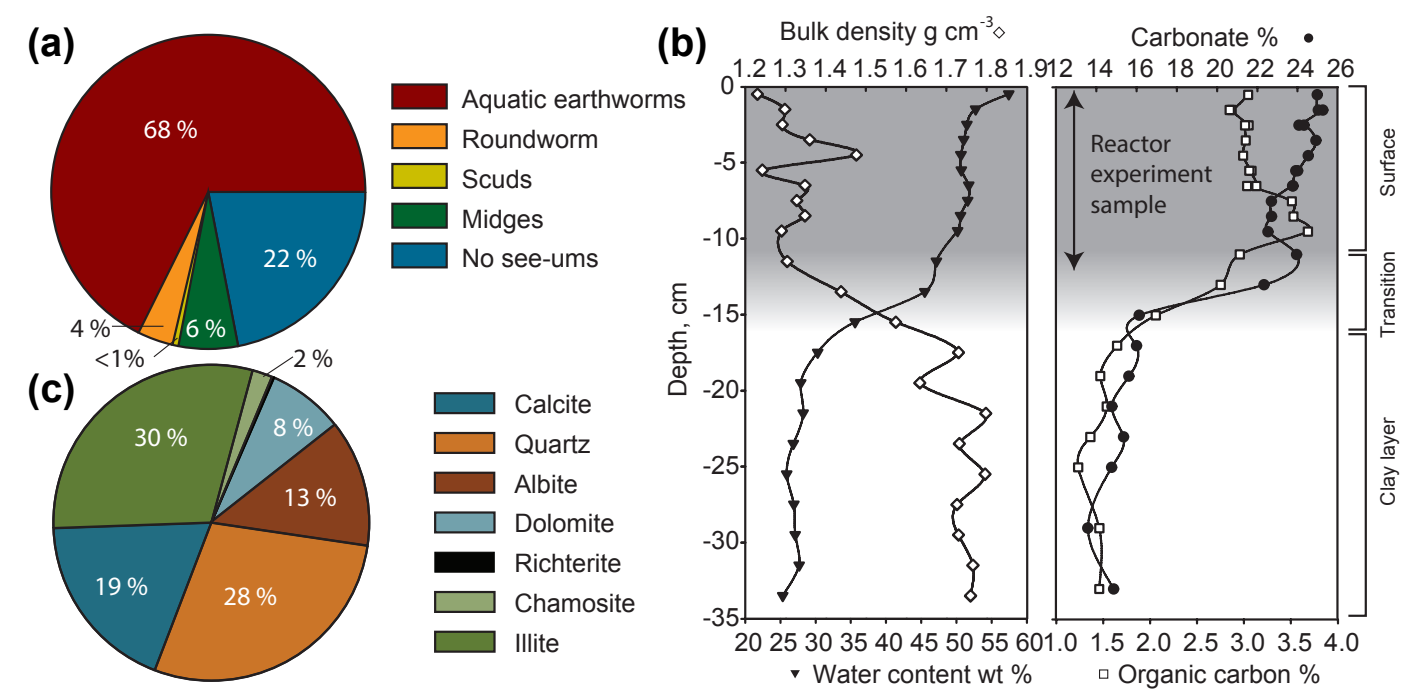

Figure 2. (a) Proportions of bioturbating macro-invertebrates identified in the top $18 \mathrm{~cm}$. (b) Depth profiles of sampled sediment, water content weight \% (inverted black triangles), bulk density (white diamonds) OM \% (white squares) and carbonate \% (black circles). (c) Mineralogical composition of sediments from the zone of bioturbation determined by XRD (top $12 \mathrm{~cm}$ ).

\subsection{Extracellular enzyme assays}

Rates of enzymatic hydrolysis of $\mathrm{P}_{\mathrm{o}}$ were estimated through extracellular enzyme activities. Degradation rates for phosphomonoesters, phosphodiesters and pyrophosphate were determined fluorometrically through use of the MUF-tagged substrates: MUF phosphate (MUP), bis(MUF)phosphate (DiMUP, Chem-Impex International) and MUF pyrophosphate (PYRO-P, Chem-Impex International) respectively. Additionally MUF $\beta$-D-glucopyranoside (MUGb) was used in order to compare phosphatase enzyme activity to the activity of $\beta$-glucosidase (cellulase) (Dunn et al., 2013). Enzyme activities were determined using a microplate reader (Flexstation3, Molecular Devices) using a modification of Deng et al. (2013). Briefly, $1 \mathrm{~g}$ dry weight equivalent of suspension from the reactor was stirred with $100 \mathrm{~mL}$ of $100 \mathrm{mM}$ HEPES buffer at $\mathrm{pH} 7.5$ in a pyrex dish for $10 \mathrm{~min}$ at $280 \mathrm{rpm}$ to allow for complete homogenization. Subsamples $(100 \mu \mathrm{L})$ of the buffered soil suspension were removed during continuous mixing using a multi-channel pipette and placed into microplate wells, which were loaded into the microplate reader. Four replicate wells were filled per substrate. Plates were left to equilibrate at $30^{\circ} \mathrm{C}$ for $5 \mathrm{~min}$ inside the reader before the automatic addition of $100 \mu \mathrm{L}$ of substrate, resulting in a final substrate concentration of $667 \mu \mathrm{M}$. Each well was triturated thoroughly during addition of the substrate. Excitation fluorescence was set at $365 \mathrm{~nm}$. Emission intensity at $450 \mathrm{~nm}$ was recorded at $5 \mathrm{~min}$ intervals over a $6 \mathrm{~h}$ period. The effect of fluorescence quenching was accounted for in each sample by preparing MUF calibration curves in the same soil suspension as used for the analysis. The limits of detection and quantification were determined to be 1.1 and $3.3 \mu \mathrm{M}$ MUF respectively, equivalent to $1.1 \mu \mathrm{M}$ of phosphate for the determination of phosphomonoesterase activities.

\section{Results and discussion}

\subsection{Sediment characterization and evidence of bioturbation}

Characterization of sediment cores revealed physical and chemical solid-phase homogeneity within the top $10 \mathrm{~cm}$, with a bulk density of $\sim 1.3 \mathrm{~g} \mathrm{~cm}^{-3}$, water content of $\sim 50 \%$ (by weight), OM of $\sim 3 \%$ and a carbonate of $\sim 25 \%$ (Fig. 2b). Between 10 and $15 \mathrm{~cm}$ depth increases in bulk density and decreases to the sediment water content, OM \% and carbonate fraction occurred as soft sediment transitioned to clay.

A benthic macro-invertebrate density of approximately 49500 individuals per $\mathrm{m}^{2}$ was determined, consistent with previously reported values (Pelegri and Blackburn, 1995). The community (Fig. 2a) was dominated by aquatic earthworms (Tubificidae $60 \%$ and Branchiura sowerbyi $8 \%$ ), which typically feed and mix sediment within the top 5$10 \mathrm{~cm}$ (Fisher et al., 1980; McCall and Fisher, 1980). Other groups identified included Ceratopogonidae (no-see-ums or biting midges, $22 \%$ ) including Sphaeromias, Probezzia, Bezzia and Chironomidae (midges, 6\%) including Cryptochironomus, Tanypus and Nemotoda (round worms, $4 \%$ ), and a single Hyalella azteca (scud $<1 \%$ ).

Bioturbating organisms, such as those identified, have previously been shown to alter biogeochemical cycling within surface sediments (Hölker et al., 2015). Reported influences include increased solute fluxes (Furukawa et al., 2001; Ma- 
tisoff and Wang, 1998), mixing of solid sediment (Fisher et al., 1980) and bioconveying of sediment particles (Lagauzère et al., 2009). These processes have been shown to enhance sediment oxygen demand (McCall and Fisher, 1980; Pelegri and Blackburn, 1995), degradation of OM (Aller, 1994), rates of denitrification, transport of contaminants to surface water (Lagauzère et al., 2009) and temporal fluctuation of redox conditions (Aller, 1994). Efficient sediment mixing allows frequent re-oxidation of reduced sediments and therefore regeneration of terminal electron acceptors (TEAs) such as nitrate, ferric iron and sulfate, which often limit mineralization of OM in sediments underlying hypereutrophic water bodies (Reddy and DeLaune, 2008). Electron donors in the form of fresh autochthonous necromass are also rapidly redistributed vertically within the zone of bioturbation. This environment should therefore support a metabolically diverse, abundant and highly active microbial community (DeAngelis et al., 2010).

Quantitative XRD analysis of the top $12 \mathrm{~cm}$ of sediment (Fig. 2c) showed close agreement with the carbonate fraction determined by TGA ( $\sim 25 \%$ by TGA vs. $27 \%$ by XRD) indicating a calcite-dominated, carbonate-buffered system. The remaining mineral assemblage was dominated by quartz and clay minerals (illite $30 \%$ and chamosite $2 \%$ ). No pyrite or vivianite was detected by XRD, suggesting either their absence or presence in low abundance $(<1 \%)$ with poorly crystalline structures.

\subsection{Experimental redox oscillation: aqueous chemistry}

$E_{h}$ within the bioreactor oscillated between +470 and $-250 \mathrm{mV}$ (Fig. 3) consistent with $E_{h}$ ranges of wetland sediments (Nikolausz et al., 2008). A slight pH oscillation was also present between $\sim 7.4$ during anoxic halfcycles $\left(\mathrm{N}_{2}\right.$ sparging) and $\sim 7.7$ during oxic half-cycles $\left(\mathrm{N}_{2}: \mathrm{O}_{2}: \mathrm{CO}_{2}\right.$ sparging $)$ this variation, shown in Fig. 3 , is consistent with calcite/dolomite-buffered sediment equilibrating with changing $p_{\mathrm{CO}_{2}}$ caused by sparging gas composition and microbial respiration. After the 11-day equilibration, ionic strength of the aqueous phase in the reactor suspension remained at $\sim 0.025 \pm 0.004 \mathrm{M}$ for the duration of the experiment. This range of $E_{h} / \mathrm{pH}$ conditions and ionic strength is consistent with the range measured within surficial sediment at the field site and transitions across the thermodynamically predicted stability boundaries for multiple redox couples, e.g. $\mathrm{MnO}_{2} / \mathrm{Mn}^{2+}, \mathrm{NO}_{3}^{-} / \mathrm{NO}_{2}^{-} / \mathrm{NH}_{4}^{+}$, $\mathrm{Fe}(\mathrm{OH})_{3} / \mathrm{Fe}^{2+}, \mathrm{SO}_{4}^{2-} / \mathrm{HS}^{-}$, during each 14-day redox cycle. The upper $E_{h}$ values recorded during oxic cycles are significantly lower than predicted by the $\mathrm{O}_{2} / \mathrm{H}_{2} \mathrm{O}$ couple $\left(820 \mathrm{mV}\right.$ at $\mathrm{pH}$ 7) but are consistent with the $\mathrm{O}_{2} / \mathrm{H}_{2} \mathrm{O}_{2}$ couple $(300 \mathrm{mV}$ at $\mathrm{pH} 7)$, which is considered to control electrode measured $E_{h}$ under oxic conditions (Stumm and Morgan, 1996).

Aqueous chemistry data, shown in Fig. 3, demonstrate the consumption of TEAs in order of decreasing nominal en-

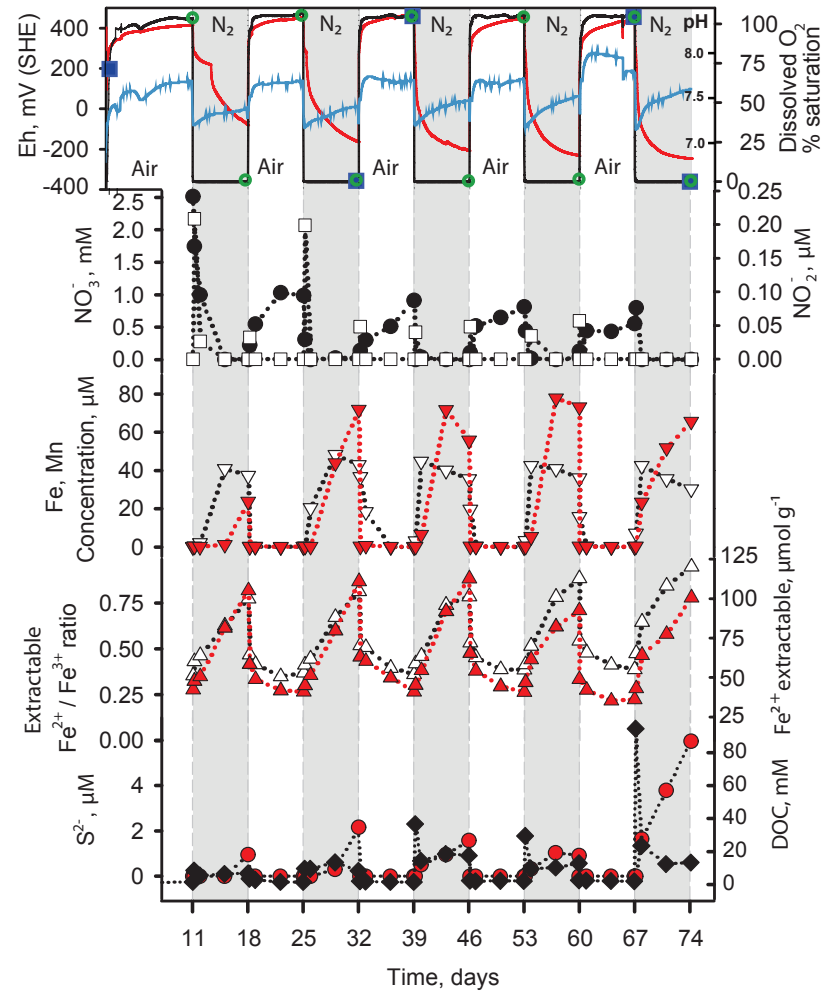

Figure 3. Aqueous chemistry and iron extraction data with time during reactor experiments: the solid red line is $E_{h}$, solid black line is $\mathrm{DO}$, solid blue line is $\mathrm{pH}$, full black circles are $\mathrm{NO}_{3}^{-}$, white squares are $\mathrm{NO}_{2}^{-}$, inverted red triangles are $\mathrm{Fe}_{(\mathrm{aq})}$, inverted white triangles are $\mathrm{Mn}_{(\mathrm{aq})}$, red triangles are $\mathrm{Fe}^{2+} 0.5 \mathrm{M} \mathrm{HCl}$ extractable, white triangles are $\mathrm{Fe}^{2+} / \mathrm{Fe}^{3+}$ ratio in $0.5 \mathrm{M} \mathrm{HCl}$ extract, red circles are $\mathrm{S}_{2}^{-}$ and black diamonds are DOC. Sampling points for ${ }^{31} \mathrm{P}$ NMR and extracellular enzyme assays (EEA) are shown on the $E_{h}$ curve $\left({ }^{31} \mathrm{P}\right.$ NMR is indicated by open blue squares and EEA by open green circles).

ergetic yield, coupled to the oxidation of labile OM. Upon physical removal and consumption of residual oxygen by aerobic respiration, nitrate concentration decreased in the solution. Decreases to nitrate concentration coincided with peaks of nitrite concentration within the first hour of oxygen removal, indicative of microbial denitrification. Subsequent increases to $\mathrm{Mn}_{(\mathrm{aq})}, \mathrm{Fe}_{(\mathrm{aq})}^{2+}$ and $\mathrm{HS}_{(\mathrm{aq})}^{-}$imply sequential reduction of $\mathrm{MnO}_{2}, \mathrm{Fe}(\mathrm{OH})_{3}$ and $\mathrm{SO}_{4}^{2-}$ as more energetically efficient electron acceptors were depleted. $\mathrm{Mn}$ (predicted as $\mathrm{Mn}^{2+}$ by the thermodynamic model) and $\mathrm{Fe}^{2+}$ were detected in solution earlier within each subsequent anoxic cycle, but the apparent order of reduction remained consistent across all five redox cycles $\left(\mathrm{O}_{2}, \mathrm{NO}_{3}^{-}, \mathrm{NO}_{2}^{-}, \mathrm{MnO}_{2}, \mathrm{Fe}(\mathrm{OH})_{3}, \mathrm{SO}_{4}^{2-}\right)$. The consistent order and relative magnitude of reduction imply that the main biogeochemical functioning of the sediment suspension did not change dramatically between cycles during the experiment. 
Although relatively low concentrations of $\mathrm{Fe}^{2+}$ (up to $71 \mu \mathrm{M})$ were measured in solution, $0.5 \mathrm{M} \mathrm{HCl}$ extractions revealed that significantly greater $\mathrm{Fe}^{2+}$ was produced during each anoxic cycle than was measured in the aqueous phase. $\mathrm{Fe}^{2+}$ generated by dissimilatory iron reduction has been shown to sorb to mineral surfaces in sediment (Gehin et al., 2007; Klein et al., 2010; Liger et al., 1999) or precipitate as ferrous carbonate (Jensen et al., 2002), ferrous sulfide or other mixed ferrous/ferric phases (Rickard and Morse, 2005). The $0.5 \mathrm{M} \mathrm{HCl}$ extractions targeted this sorbed or poorly crystalline freshly precipitated $\mathrm{Fe}^{2+}$. During each anoxic cycle $\mathrm{HCl}$ extractable $\mathrm{Fe}^{2+}$ concentration increased by $50-$ $70 \mu \mathrm{mol} \mathrm{g}^{-1}$, equivalent to 12.31 to $17.29 \mathrm{mM}$ of iron reduction within the reactor as a whole. Thus, only $0.63 \pm 0.4 \%$ of microbially reduced $\mathrm{Fe}^{2+}$ was measurable in solution. The aqueous phase of the reactor was shown to be supersaturated with respect to mackinawite $(\mathrm{FeS})$, pyrite $\left(\mathrm{FeS}_{2}\right)$, vivianite $\left(\mathrm{Fe}_{3}\left(\mathrm{PO}_{4}\right)_{2}: 8 \mathrm{H}_{2} \mathrm{O}\right)$ and siderite $\left(\mathrm{FeCO}_{3}\right)$ during anoxic halfcycles, indicating thermodynamic favorability for precipitation of these minerals. The kinetic constraints on precipitation were not, however, considered. No significant cumulative change to extractable $\mathrm{Fe}^{2+} / \mathrm{Fe}^{3+}$ occurred after five full reduction-oxidation cycles, indicating that solid-phase Fe redox cycling was reversible, potentially due to rapid oxidation of solid $\mathrm{Fe}^{2+}$ in the presence of $\mathrm{O}_{2}$ and carbonate (Caldeira et al., 2010).

DOC concentration also fluctuated systematically during oxic-anoxic cycles (Fig. 3). Higher DOC concentrations were measured during anoxic conditions than oxic conditions. DOC may be replenished by both enzymatic hydrolysis of particulate organic matter (Vetter et al., 1998) and desorption of mineral-associated OM (Grybos et al., 2009). The addition of algal matter at the beginning of anoxic cycles resulted in observable sharp peaks of DOC, which was rapidly removed from solution, probably due to a combination of mineralization of labile DOC to $\mathrm{HCO}_{3}^{-}$and sorption processes (Chorover and Amistadi, 2001; Grybos et al., 2009). The peak of DOC supplied by addition of algal matter represented labile DOC, which was readily mineralized in comparison to the residual DOC, which persisted in the system throughout the experiment. The differences in residual OM mobility between oxic and anoxic cycles were unlikely due to oxide dissolution as differences to DOC concentration are observed prior to increases in $\mathrm{Mn}$ and $\mathrm{Fe}$ concentration in solution. We therefore postulate that solubility changes to humified DOC were driven by $\mathrm{pH}$ changes (Fig. 3) between oxic and anoxic conditions caused by changes in $p \mathrm{CO}_{2}$ between oxic and anoxic conditions as previously shown in wetland sediments (Grybos et al., 2009).

Lowest aqueous phosphorus concentrations $(\sim 2.5-3 \mu \mathrm{M})$, shown in Fig. 4, occurred during oxic half-cycles and increased dramatically during anoxic half-cycles to a maximum concentration of 50-60 $\mu \mathrm{M}$ per cycle, $88 \%$ of which occurred as SRP. The range of TDP concentrations within the aqueous phase of the reactor suspension is similar to that re-

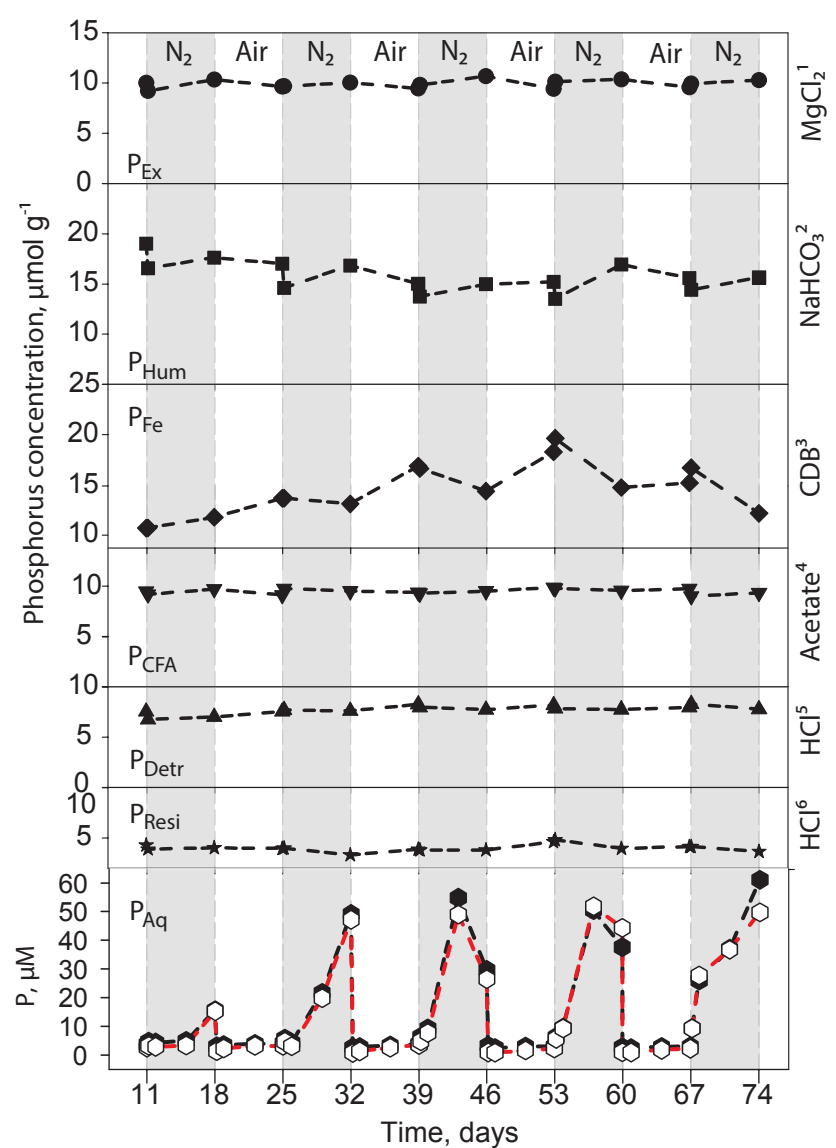

Figure 4. Aqueous- and solid-phase phosphorus speciation from sequential chemical extractions with time during the reactor experiment. White panels correspond to time periods with air sparging, and grey panels correspond to time periods with $\mathrm{N}_{2}: \mathrm{CO}_{2}$ sparging. Black symbols are total $\mathrm{P}$ concentration, and white symbols are SRP concentration.

ported in situ at the field site by Mayer et al. (2006). The timing of phosphorus release to the aqueous phase corresponded well with increasing $\mathrm{Fe}_{(\text {aq) }}^{2+}$ concentration. This is reflected in a strong positive correlation between TDP and Fe concentrations $\left(\mathrm{n}=37, \mathrm{R}^{2}=0.93, p<0.0001\right)$. Increases to aqueous $\mathrm{P}$ concentration occurred only after depletion of residual $\mathrm{O}_{2}, \mathrm{NO}_{3}^{-}$and $\mathrm{NO}_{2}^{-}$, after increases to $\mathrm{Mn}_{(\mathrm{aq})}$ and before increases to $\mathrm{HS}_{(\mathrm{aq})}^{-}$. The timing of $\mathrm{P}$ release is suggestive of an iron(III)-oxyhydroxide or ferric phosphate control on phosphorus mobility (Bonneville et al., 2004; Hyacinthe and Van Cappellen, 2004) and indicates that complete nitrate depletion was required prior to phosphorus release to the aqueous phase.

\subsection{Sequential chemical extractions and solid-phase $\mathbf{P}$ partitioning}

The sum of $\mathrm{P}$ concentrations from all sequential extraction reservoirs $\left(61 \pm 5 \mu \mathrm{mol} \mathrm{g}^{-1}\right)$ was consistently within $10 \%$ 
of a total P extraction $\left(57 \pm 4 \mu \mathrm{mol} \mathrm{g}^{-1}\right)$, indicating acceptable analytical precision from the sequential extraction procedure. Highest $\mathrm{P}$ concentrations were associated with the $\mathrm{P}_{\text {Hum }}\left(\sim 26 \%\right.$ of TP) and $\mathrm{P}_{\mathrm{Fe}}(\sim 24 \%)$ fractions with lower $\mathrm{P}$ concentrations in the $\mathrm{P}_{\mathrm{Ex}} \sim 16 \%, \mathrm{P}_{\mathrm{CFA}} \sim 15 \%, \mathrm{P}_{\text {Detr }} \sim 12 \%$ and $\mathrm{P}_{\mathrm{Res}} \sim 7 \%$ fractions (Fig. 4). The largest variations in $\mathrm{P}$ concentration were observed for $\mathrm{P}_{\mathrm{Fe}}$ and decreased in the order $\mathrm{P}_{\mathrm{Fe}}(2.6)>\mathrm{P}_{\text {Hum }}(1.5)>\mathrm{P}_{\mathrm{Ex}}(0.4)>\mathrm{P}_{\text {Detr }}(0.4)>\mathrm{P}_{\text {Resi }}$ $(0.35)>P_{C F A}(0.25)$, where the numbers in parentheses are standard deviations $\left(\mu \mathrm{mol} \mathrm{g}^{-1}\right)$. High variability over time within the $\mathrm{P}_{\mathrm{Fe}}$ and $\mathrm{P}_{\mathrm{Hum}}$ fractions suggests that $\mathrm{P}$ was exchanged to and from these fractions during redox oscillation, whereas changes to the $\mathrm{P}_{\mathrm{Ex}}, \mathrm{P}_{\mathrm{Resi}}$ and $\mathrm{P}_{\mathrm{CFA}}$ fractions were comparatively insignificant (Fig. 4).

The $\mathrm{P}_{\mathrm{Fe}}$ fraction was the only $\mathrm{P}$ pool in which concentration consistently decreased during anoxic conditions and increased during oxic conditions (Fig. 4). When a P mass balance (Fig. 5) was attempted to account for increases to aqueous phosphorus $\left(\mathrm{P}_{\mathrm{Aq}}\right)$ from the iron-bound $\left(\mathrm{P}_{\mathrm{Fe}}\right)$ pool during anoxic periods, it became evident that only approximately $4.5 \%$ of variability observed in the $\mathrm{P}_{\mathrm{Fe}}$ pool (total $\mathrm{P}_{\mathrm{Fe}}$ variation of up to $4.5 \mu \mathrm{mol} \mathrm{g}{ }^{-1}$ during anoxic periods) was necessary to account for the changes to inter-cycle $\mathrm{P}_{\mathrm{Aq}}$ concentrations $(50 \mu \mathrm{M})$. The remainder of $\mathrm{P}_{\mathrm{Fe}}$ lost during anoxic cycles appears to be reversibly redistributed to the $\mathrm{P}_{\mathrm{Ex}}(\sim 30 \%)$ and $\mathrm{P}_{\mathrm{Hum}}(\sim 65 \%)$ pools, which generally increased during anoxic conditions and decreased during oxic conditions (Fig. 4).

According to Ruttenberg (1992) the $\mathrm{P}_{\mathrm{Ex}}$ fraction corresponds to $\mathrm{P}$ mobilized via the formation of $\mathrm{MgPO}_{4}^{-}$complexes and(or) mass action displacement by $\mathrm{Cl}^{-}$. It is therefore considered that $\mathrm{MgCl}_{2}$ effectively extracts $\mathrm{P}$ loosely associated with mineral surfaces. However, Ruttenberg (1992) also demonstrated that plankton were efficiently extracted by $\mathrm{MgCl}_{2}$ as well as $\sim 25 \%$ of $\mathrm{P}$ associated with biogenic $\mathrm{CaCO}_{3}$. Consequently, it is likely that $\mathrm{P}$ associated with microbial biomass, $\mathrm{CaCO}_{3}$, and other loosely sorbed $\mathrm{P}$ contributed to the $\mathrm{P}_{\mathrm{Ex}}$ fraction. Slight increases to $\mathrm{P}_{\mathrm{Ex}}$ concentration during anoxic periods and corresponding decreases during oxic periods likely reflect the combination of two processes: (1) equilibration between $P$ surface complexes and aqueous $\mathrm{P}$ species due to fluctuating aqueous concentrations which were consistently higher during anoxic periods (Olsen and Watanabe, 1957); and (2) pH-driven sorption/desorption as $\mathrm{pH}$ was consistently slightly higher during aerobic periods (Fig. 3), favouring desorption from mineral surfaces including illite, which comprised $30 \%$ of the crystalline mineralogical fraction (Fig. 2c) (Manning, 1996).

The $\mathrm{NaHCO}_{3}$ extraction step was originally added to the SEDEX method to target OM-associated $\mathrm{P}$, which would otherwise be liberated during the $\mathrm{P}_{\mathrm{Fe}}$ extraction step (Baldwin, 1996). Baldwin noted a brown coloration in $P_{\text {Hum }}$ extracts and that absorbance at $250 \mathrm{~nm}$ was positively correlated with SRP. Absorbance at $254 \mathrm{~nm}$ has been shown to be indicative of aromatic OM, commonly associated with humic sub-

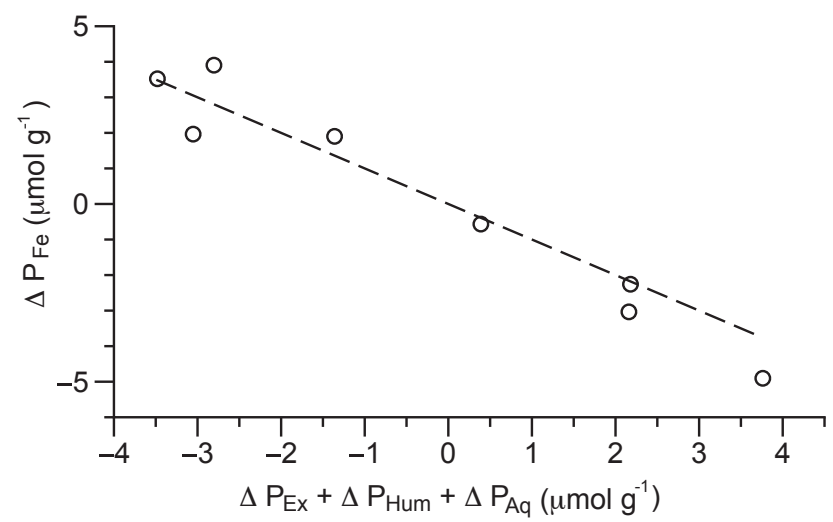

Figure 5. Change in $\mathrm{P}$ distribution between the start and end of each oxic and anoxic period (7-day change). Iron-bound $\mathrm{P}\left(\mathrm{P}_{\mathrm{Fe}}\right)$ appears to be reversibly redistributed to the loosely sorbed $\left(\mathrm{P}_{\mathrm{Ex}}\right)$ and humic-bound $\left(\mathrm{P}_{\mathrm{Hum}}\right)$ and aqueous fractions $\left(\mathrm{P}_{\mathrm{Aq}}\right)$. The dashed line is $1: 1$. Linear regression of the data results in an $R^{2}$ of 0.95 , a slope of -1.1 and $p<0.0001)$.

stances (Weishaar et al., 2003). A light brown colour was also present in the $\mathrm{NaHCO}_{3}$ extracts recovered during this experiment despite comparatively low sediment OM content (Fig. 2b). Absorbance spectra for these extracts were not determined.

$\mathrm{Li}$ et al. (2015) have recently demonstrated that the SEDEX $\mathrm{P}_{\mathrm{Fe}}$ extraction step co-extracted $\mathrm{P}$ associated with fine iron oxide-OM complexes when a prior $\mathrm{NaHCO}_{3}$ step was not incorporated. However, $\mathrm{Li}$ et al. (2015) also suggested that these complexes may be more recalcitrant than pure minerals. Iron was present within the $\mathrm{P}_{\mathrm{Hum}}$ extract at concentrations between 18 and $25 \mu \mathrm{mol} \mathrm{g}{ }^{-1}$, but the original speciation of this iron is prior to extraction is unknown. Chemically similar extractions used in soil sciences such as Hedley's extraction $\left(0.5 \mathrm{M} \mathrm{NaHCO}_{3}, \mathrm{pH} 8.5,16 \mathrm{~h}\right)$ and the Olsen P test $\left(0.5 \mathrm{M} \mathrm{NaHCO}_{3}, \mathrm{pH} 8.5,30 \mathrm{~min}\right)$ have been shown to extract $\mathrm{Mg}$ and $\mathrm{Ca}$ phosphates as well as some organic P (Hedley et al., 1982; Olsen et al., 1954). Approximately two-thirds of $\mathrm{P}$ extracted within $\mathrm{P}_{\mathrm{Hum}}$ was present as SRP, suggesting that approximately one-third of this fraction may be $\mathrm{P}_{\mathrm{o}}$ species. The $\mathrm{pH}$ of the $\mathrm{NaHCO}_{3}$ extract used here was adjusted to 7.6 to minimize the dissolution of $\mathrm{Mg}$ and $\mathrm{Ca}$ phosphates prior to the $\mathrm{P}_{\mathrm{CFA}}$ extraction. Despite this, $30-44 \mu \mathrm{mol} \mathrm{g}{ }^{-1}$ of $\mathrm{Ca}$ was extracted within the $\mathrm{P}_{\text {Hum }}$ fraction. The origin of the extracted $\mathrm{Ca}$ is, however, unknown and may have been complexed with OM or part of labile Ca phosphates. It is still expected that the majority of Ca-phosphate minerals were quantified as part of the $\mathrm{P}_{\mathrm{CFA}}$ or $\mathrm{P}_{\text {Detri }}$ extractions, which included $\sim 500-700$ and $\sim 50-70 \mu \mathrm{mol} \mathrm{Ca} \mathrm{g}^{-1}$ respectively.

Humic acids are known to compete with orthophosphate for surface-binding sites on various minerals, including goethite (Sibanda and Young, 1986) and poorly ordered Feoxides in the short term (Gerke, 1993). However, sorption 
of natural $\mathrm{OM}$ to freshly precipitated Fe oxides may increase the long-term sorption capacity of ferric oxides towards $\mathrm{P}$ by decreasing recrystallization over time (Gerke, 1993) and through the formation of OM-Fe-P complexes (Gerke, 1993). Although previous studies have provided evidence for ternary complexes between ferric iron, $\mathrm{OM}$ and phosphate (Kizewski et al., 2010b) there is currently no direct spectroscopic evidence for the existence of mixed OM$\mathrm{Fe}(\mathrm{III})$-phosphate complexes in natural waters. Identification of such complexes in natural environments is inherently challenging due to the complexity of natural geochemical matrices (Kizewski et al., 2010a). Recent studies have however successfully investigated the structure of synthetic $\mathrm{OM}-\mathrm{Fe}(\mathrm{III})-$ phosphate complexes (Kizewski et al., 2010a) and similar OM-Fe(III)-arsenate complexes spectroscopically (Mikutta and Kretzschmar, 2011; Sharma et al., 2010). These studies suggest that similar and perhaps more complex heterogeneous ternary complexes are also likely to be present in natural freshwater environments (Kizewski et al., 2010a). This suggestion is also supported by the observation that more than $80 \%$ of soluble $\mathrm{P}$ in some natural waters is associated with high molecular weight OM (Gerke, 2010). As spectroscopic characterization of the $\mathrm{P}$ associated with the $\mathrm{P}_{\mathrm{Hum}}$ fraction was not performed in this study, the $\mathrm{P}_{\mathrm{Hum}}$ pool is considered to represent a variety of OM-associated $P$ in addition to small amounts of $\mathrm{P}$ from labile Ca-phosphate minerals. OM-associated $\mathrm{P}$ extracted within this fraction is likely coordinated with ferric iron $\left(18-25 \mu \mathrm{mol} \mathrm{Fe} \mathrm{g}^{-1}\right.$ coextracted), $\mathrm{Ca}\left(30-44 \mu \mathrm{mol} \mathrm{Ca} \mathrm{g}{ }^{-1}\right.$ co-extracted) or $\mathrm{Al}(0.8-$ $1.5 \mu \mathrm{mol} \mathrm{Al} \mathrm{g}{ }^{-1}$ co-extracted). These metals may, in turn, be associated with various mineral surfaces within the sediment.

Sequential extraction data demonstrate that the $\mathrm{P}_{\mathrm{Hum}}$ fraction is the dominant $P$ fraction in all samples analysed, which highlights the significance of this fraction. P mass balance also suggests that reversible re-partitioning between this and the $\mathrm{P}_{\mathrm{Fe}}$ fraction occurs during redox condition changes. As the exact chemical nature of the $\mathrm{P}_{\mathrm{Hum}}$ fraction is not known, interpretation of concentration changes over time are challenging. Speculatively, increases to the $\mathrm{P}_{\mathrm{Hum}}$ fraction under anoxic conditions may be due to the release of occluded $\mathrm{OM}-$ metal-P complexes within iron(III) oxyhydroxides during reductive dissolution or simply re-equilibration of solid-phase OM-metal-P complexes with increased aqueous $\mathrm{P}$.

We consider that the majority of $\mathrm{P}$ extracted within the $\mathrm{P}_{\mathrm{Fe}}$ fraction was co-precipitated with iron(III) oxyhydroxides which were reductively dissolved by dithionite during the extraction (Ruttenberg, 1992). This interpretation is supported by the relatively high concentrations of iron extracted within the $\mathrm{P}_{\mathrm{Fe}}$ fraction $\left(72-91 \mu \mathrm{mol} \mathrm{Fe} \mathrm{g}{ }^{-1}\right)$. Aqueous $\mathrm{Fe}^{2+}$ produced during this extraction is subsequently chelated by citrate and therefore solubility of $\mathrm{Fe}$ and $\mathrm{P}$ is maintained. The bicarbonate component functions as a $\mathrm{pH}$ buffer to ensure maximum preservation of apatite and $\mathrm{CaCO}_{3}$-bound $\mathrm{P}$ during this reaction step (Ruttenberg, 1992).
Neither the $\mathrm{P}_{\mathrm{CFA}}, \mathrm{P}_{\text {Detri }}$ nor $\mathrm{P}_{\text {Resi }}$ fractions varied systematically between oxic and anoxic conditions or changed consistently during the course of the experiment, suggesting their comparative stability during short periods of redox fluctuation. This is supported by calculated SI for hydroxyapatite, which remained between +0.86 and +6.24 for the duration of the experiment.

The $\mathrm{P}$ contribution from individual algal additions $\left(\sim 1.5 \mu \mathrm{mol} \mathrm{P} \mathrm{g}^{-1}\right)$ was relatively small compared to total $\mathrm{P}$

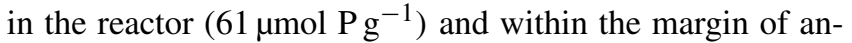
alytical error associated with solid extractions. Additionally, no single fraction shows a clear increase over the course of the experiment, and therefore quantification of the redistribution of $\mathrm{P}$ added with algal additions is not possible.

\section{$3.4 \quad F e: P$ ratios}

Sequential extraction data (shown in Fig. 4), aqueous chemistry data (shown in Fig. 3) and the correlation between aqueous $\mathrm{Fe}$ and $\mathrm{P}\left(\mathrm{n}=37, \mathrm{R}^{2}=0.93, p<0.0001\right)$ all suggest that $\mathrm{P}$ released to solution under anoxic conditions originated in the $\mathrm{P}_{\mathrm{Fe}}$ pool. Although the maximum molar ratio for phosphate incorporation within ferric oxides has been shown to be $2: 1$ (Fe: P) (Thibault et al., 2009), it has been suggested that much higher solid Fe : $\mathrm{P}$ of 15 (Jensen et al., 1992) to $>20$ (Phillips et al., 1994) may be necessary to control phosphorus mobility under oxic conditions. Results from bioreactor experiments suggest that phosphorus is retained in the solid phase under oxic conditions at total $\mathrm{Fe}: \mathrm{P}$ ratios of just $4.1: 1$, potentially due to the association of $\mathrm{P}$ with other solid sedimentary pools, particularly $\mathrm{P}_{\mathrm{Hum}}$. Fe : $\mathrm{P}$ ratios below the stoichiometric limitation of $2: 1$, measured in the aqueous phase (1.5-1.9), during anoxic conditions are therefore likely due to the removal of $\mathrm{Fe}^{2+}$ from solution by secondary sorption and precipitation processes, subsequent to reductive dissolution. Probable secondary $\mathrm{Fe}^{2+}$ removal processes include the formation of amorphous FeS (SI of up to +2.27 for mackinawite) (Rickard and Morse, 2005) and sorption of $\mathrm{Fe}^{2+}$ to clays (Gehin et al., 2007; Klein et al., 2010). This is supported by increases to $\mathrm{Fe}^{2+} / \mathrm{Fe}^{3+}$ ratios in the $0.5 \mathrm{M} \mathrm{HCl}$ extractable fraction during anoxic conditions. Frequent rapid reoxidation of ferrous sulfide due to air sparging in the reactor experiment, and extensive in situ bioturbation, likely prevents formation of more recalcitrant and slow-forming iron sulfide minerals such as pyrite, despite strong thermodynamic favorability for pyrite formation (SI up to +13.13) (Caldeira et al., 2010; Peiffer et al., 2015). This is consistent with the results of XRD analysis, which did not identify pyrite (Fig. 2c). A similar effect has been previously demonstrated in lake sediments (Gächter and Müller, 2003).

\subsection{Hydrolytic enzyme activities}

The activities of model phosphomonoesterase, phosphodiesterase and pyrophosphatase were found to be systemati- 


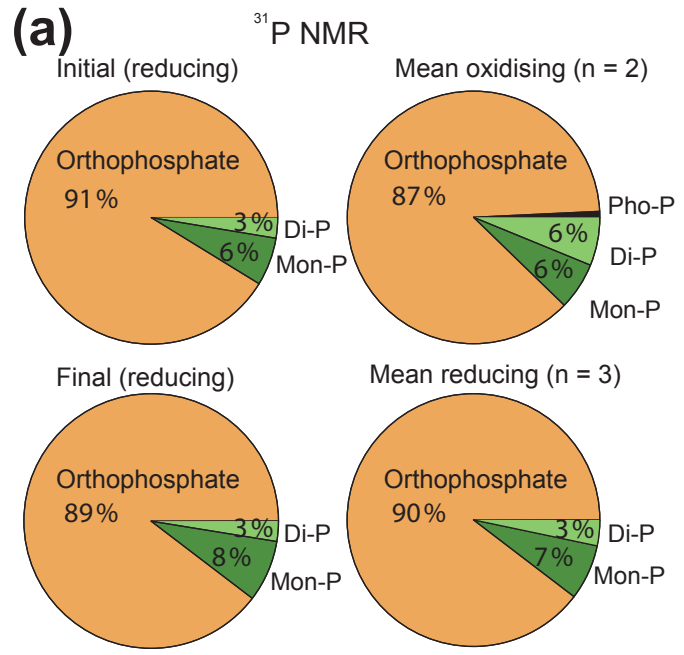

(b) Enzymatic activity assays

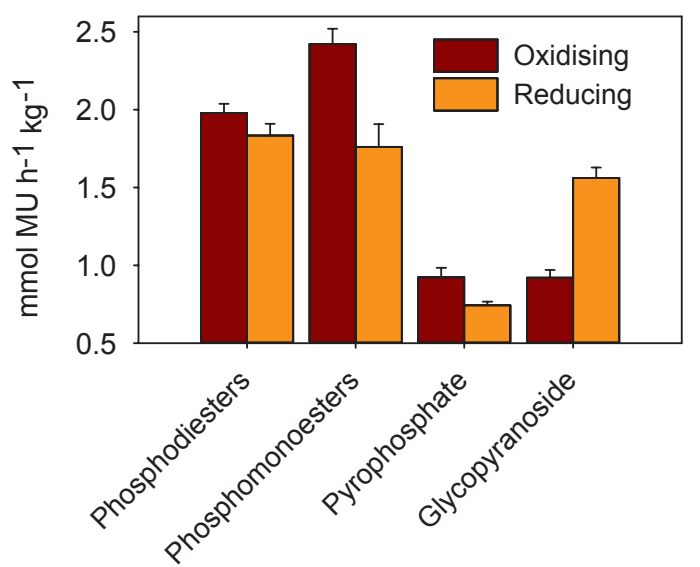

Figure 6. (a) P speciation determined by ${ }^{31} \mathrm{P}$ NMR for the initial suspension (top left), the final suspension (bottom left) and the average of samples from oxic conditions $n=2$ (top right), the average of samples from anoxic conditions $n=3$ (bottom right). Pho-P is phosphonates, Di-P is diester P and Mon-P is monoester P. Polyphosphate was not detected at concentrations $>1 \%$ in any of the samples analysed. (b) Average extracellular enzyme activities under oxic and anoxic conditions for MUP, DiMUP, PYRO-P and MUGb ( $n=5)$.

cally higher under oxic conditions compared to anoxic conditions by $37 \%(p<0.005), 8 \%$ (not significant) and $24 \%$ $(\mathrm{p}=0.08)$ respectively (Fig. 6b). Phosphomonoesterases were found to have the highest activities despite the inherent overestimation of phosphodiesterase activities when using MUF-tagged substrates (Sirová et al., 2013). The opposite trend was observed for glycopyranoside, part of the cellulose degradation pathway (Dunn et al., 2013), which showed consistently higher activity $(69 \% p=<0.05)$ under anoxic conditions (Fig. 6b). The different trends exhibited by cellulose and phosphatase enzymes indicate that changes in activity were not universal but specific to enzyme function. Phosphomonoesterase activities obtained in the current study $\left(1.76-2.4 \mathrm{mmol} \mathrm{h}^{-1} \mathrm{~kg}^{-1}\right)$ are similar to those previously reported in wetland sediments (Kang and Freeman, 1999) and suggest the capacity for rapid hydrolysis of $P_{o}$ species in necromass. Lowering of the water table in wetlands has previously been shown to increase the activity of phosphatase enzymes and the hydrolysis of $\mathrm{P}_{\mathrm{o}}$ species (Song et al., 2007). However, water table fluctuation results in concomitant changes to moisture content and redox conditions, which prevents isolation of the causal variable in field investigations (Rezanezhad et al., 2014). Therefore, this is, to the best of our knowledge, the first direct demonstration of phosphatase activity changes in response to changing redox conditions. We postulate that under anoxic conditions, when phosphorus availability in the aqueous phase is high, production of extracellular phosphatase enzymes by the microbial community is down-regulated. Conversely, when bioavailable phosphorus is removed from solution under oxic conditions, extracellular phosphatase production is up-regulated in response. Adjustments to enzyme production in response to changes in phosphate availability must occur on short timescales (hours/days) for such trends to be observable during the bioreactor experiment. An inverse relationship between phosphatase activities and phosphate concentration has previously been shown spatially in wetlands by Kang and Freeman (1999) but to our knowledge never temporally in sediments.

\section{$3.6 \quad{ }^{31}$ P NMR}

Results from ${ }^{31}$ P NMR analyses (Fig. 6a) show that the majority of phosphorus was present in the solid phase as orthophosphate (84-91\%) with 4-8\% monoester P, 3-8\% diester $\mathrm{P}$ and $<1 \%$ phosphonates and polyphosphates with no clear trend in relative abundance emerging during the experiment. The NaOH-EDTA extraction resulted in a recovery of $\sim 27 \%$ of TP, which is comparable to previous studies with carbonate-buffered soils and sediments (Hansen et al., 2004; Turner et al., 2003a). Alpha and beta glycerophosphates are commonly identified in monoester spectral regions and have been demonstrated to be products of diesters degraded during analysis (Doolette et al., 2009; Jørgensen et al., 2015; Paraskova et al., 2015). As no glycerophosphates were identified in any of the analysed samples, recalculation of monoester / diester ratios was not performed. A higher mean monoester / diester ratio (2.31) was found in reduced samples than oxidized samples (0.97) (a statistically significant difference, $p=0.04$ ). This difference could indicate either that monoester $\mathrm{P}$ was less efficiently extracted under oxic conditions due to sorption to metal oxides or that monoesterase/diesterase activity decreased under anoxic conditions, which is consistent with enzymatic activity assays 
(Fig. 6b). Total $\mathrm{P}_{\mathrm{o}}$ determined by ${ }^{31} \mathrm{P}$ NMR varied between 9 and $16 \%$ over time compared to $5-11 \%$ in the $\mathrm{P}_{\text {resi }}$ from sequential extractions, indicating that not all $\mathrm{P}_{\mathrm{o}}$ was extracted in the $\mathrm{P}_{\text {resi }}$ fraction, which is commonly referred to as the organic-P fraction. We postulate that the remaining $\sim 5 \%$ of total phosphorus, identified as $\mathrm{P}_{\mathrm{O}}$ by ${ }^{31} \mathrm{P} \mathrm{NMR}$, was extracted during previous steps in the sequential extraction scheme, particularly $\mathrm{MgCl}_{2}$, which has been shown to efficiently extract $\mathrm{P}$ associated with microbial biomass (Ruttenberg, 1992) and $\mathrm{NaHCO}_{3}$. The relative activities of phosphatase enzymes appear to correlate with the relative abundances of $\mathrm{P}_{\mathrm{O}}$ species identified by ${ }^{31} \mathrm{P}$ NMR, e.g. monoesters $>$ diesters $>$ pyro-P.

Significant polyphosphate $(>1 \%)$ was not detected by ${ }^{31} \mathrm{P}$ NMR during experiments. Previous studies focusing on WWTP tertiary treatment for phosphate removal suggest that redox oscillating conditions promote intracellular poly-P accumulation during aerobic conditions to be used as an energy store under anoxic conditions in order to uptake short-chain fatty acids (SCFA) in the absence of an electron acceptor (Hupfer et al., 2007; Wentzel et al., 1991). Phosphate uptake during aerobic conditions therefore requires $\mathrm{P}$ availability in excess of what is required for growth and maintenance of the microbial community. However, phosphate availability under aerobic conditions is limited by sorption and co-precipitation with iron oxides, assuming sufficient $\mathrm{Fe}$ : $\mathrm{P}$, despite high total phosphorus concentration in sediment. The $\mathrm{P}$ requirements by the microbial community are also likely to be high during the transition to aerobic conditions due to the availability of $\mathrm{O}_{2}$ as an energetically efficient electron acceptor and fermentation products (SCFA), further decreasing the probability of polyphosphate accumulation. Additionally, polyphosphate accumulation and release has shown to be inhibited by denitrification and sulfate reduction due to competition for SCFA (Kortstee et al., 1994; Yamamoto-Ikemoto et al., 1994).

\section{Implications}

Our controlled laboratory simulation of highly dynamic redox conditions in eutrophic sediment demonstrates the importance of multiple coupled elemental cycles $(\mathrm{C}, \mathrm{N}, \mathrm{Fe}, \mathrm{S}$, $\mathrm{P})$ when determining internal $\mathrm{P}$ loading potential and timing. Our results demonstrate that neither aqueous- nor solid-phase $\mathrm{Fe}: \mathrm{P}$ ratios or even solid-phase $\mathrm{P}_{\mathrm{Fe}}$ quantification are good predictors of potential $\mathrm{P}$ release to the water column under anoxic conditions due to extensive reversible redistribution of both reduced $\mathrm{Fe}$ and associated $\mathrm{P}$ within the solid phase. We show that $99.4 \%$ of reduced $\mathrm{Fe}$ and $95.5 \%$ of $\mathrm{P}_{\mathrm{Fe}}$ are not released to the aqueous phase upon $\mathrm{Fe}$ reduction but reversibly redistributed within the solid phase upon short periods of iron reduction. Additionally, the apparent requirement for complete nitrate depletion prior to anoxia-promoted $\mathrm{P}$ release to the aqueous phase has potential implications for water bodies where significant iron-bound legacy $\mathrm{P}$ is present within sediments. Our results suggest that decreasing $\mathrm{NO}_{3}^{-}$ concentrations in external loads, while ostensibly ecologically beneficial, may, in some cases, increase the frequency and magnitude of internal $\mathrm{P}$ loading during short periods of anoxia. In $\mathrm{P}$ limited systems, the apparent ecological benefits of decreased $\mathrm{NO}_{3}^{-}$may be offset by increased $\mathrm{P}$ release and eutrophication. However, numerous additional processes exist in natural systems, which were not simulated during our reactor experiment and may influence internal loading mechanisms. Finally, we demonstrate that oscillatory redox conditions, even in sediments with diverse and active microbial communities, do not necessarily result in accumulation of polyphosphate due to mineralogical phosphate immobilization and scavenging of SCFA by anaerobic heterotrophic respiration.

Data availability. Full tabulated aqueous- and solid-phase chemistry data for the experimental time series is provided in the Supplement. 


\section{Appendix A: Abbreviations}

\begin{tabular}{|c|c|}
\hline GFA & green filamentous algae \\
\hline WWTP & waste water treatment plant \\
\hline SWI & sediment-water interface \\
\hline DOC & dissolved organic carbon \\
\hline$P_{0}$ & organic phosphorus species \\
\hline SRP & soluble reactive phosphorus \\
\hline ICP-OES & inductively coupled plasma optical emission spectrometry \\
\hline $\mathrm{OM}$ & organic matter \\
\hline XRD & powder X-ray diffraction \\
\hline MDL & method detection limit \\
\hline TDP & total dissolved phosphorus \\
\hline RSD \% & relative standard deviation \\
\hline MUF & 4-methylumbelliferyl \\
\hline MUP & 4-Methylumbelliferyl phosphate \\
\hline DiMUP & bis(4-methylumbelliferyl)phosphate \\
\hline PYRO-P & 4-methylumbelliferyl pyrophosphate \\
\hline MUGb & 4-methylumbelliferyl beta-D-glucopyranoside \\
\hline TGA & thermogravimetric analysis \\
\hline ТP & total phosphorus \\
\hline
\end{tabular}




\section{The Supplement related to this article is available online at https://doi.org/10.5194/bg-14-3585-2017-supplement.}

Competing interests. The authors declare that they have no conflict of interest.

Acknowledgements. We acknowledge funding from the Canadian Excellence Research Chair (CERC) program and the Water Institute at the University of Waterloo.

We would like to acknowledge the support of the Royal Botanical Gardens, particularly Jennifer Bowman and Tys Theymeyer as well as Taylor Maavara who kindly provided her pack raft for use during field sampling. We also acknowledge Jia Cheng (Allen) $\mathrm{Yu}$ for his assistance with the production of Fig. 1 as well as Marianne Vandergriendt, Kassandra Ma and Christine Ridenour for laboratory assistance.

Edited by: Tina Treude

Reviewed by: two anonymous referees

\section{References}

Aller, R. C.: Bioturbation and remineralization of sedimentary organic matter: effects of redox oscillation, Chem. Geol., 114, 331345, https://doi.org/10.1016/0009-2541(94)90062-0, 1994.

Aller, R. C.: Conceptual models of early diagenetic processes: The muddy seafloor as an unsteady, batch reactor, J. Mar. Res., 62, 815-835, https://doi.org/10.1357/0022240042880837, 2004.

Amirbahman, A., Lake, B. A., and Norton, S. A.: Seasonal phosphorus dynamics in the surficial sediment of two shallow temperate lakes: a solid-phase and pore-water study, Hydrobiologia, 701, 65-77, https://doi.org/10.1007/s10750-012-1257-z, 2013.

Baldwin, D. S.: The phosphorus composition of a diverse series of Australian sediments, Hydrobiologia, 335, 63-73, https://doi.org/10.1007/BF00013684, 1996.

Berner, R. A.: Stoichiometric models for nutrient regeneration $\mathrm{m}$ anoxic sediments1: Nutrient regeneration, Limnol. Oceanogr., 22, 781-786, https://doi.org/10.4319/lo.1977.22.5.0781, 1977.

Bonneville, S., Van Cappellen, P., and Behrends, T.: Microbial reduction of iron(III) oxyhydroxides: effects of mineral solubility and availability, Chem. Geol., 212, 255-268, https://doi.org/10.1016/j.chemgeo.2004.08.015, 2004.

Bowman, J. and Theysmeyer, T.: 2013 RBG Marsh Sediment Quality Assessment (No. Report No. 2014-14), Royal Botanical Gardens, Burlington, Ontario, 2014.

Cade-Menun, B. J.: Characterizing phosphorus in environmental and agricultural samples by $31 \mathrm{P}$ nuclear magnetic resonance spectroscopy, Talanta, 66, 359-371, https://doi.org/10.1016/j.talanta.2004.12.024, 2005.

Cade-Menun, B. J. and Preston, C. M.: A Comparison of Soil Extraction Procedures for 31P NMR Spectroscopy, Soil Sci., 161, 770-785, https://doi.org/10.1097/00010694-199611000-00006, 1996.
Cade-Menun, B. J., Navaratnam, J. A., and Walbridge, M. R.: Characterizing Dissolved and Particulate Phosphorus in Water with ${ }^{31} \mathrm{P}$ Nuclear Magnetic Resonance Spectroscopy, Environ. Sci. Technol., 40, 7874-7880, https://doi.org/10.1021/es061843e, 2006.

Cade-Menun, B. J., Carter, M. R., James, D. C., and Liu, C. W.: Phosphorus forms and chemistry in the soil profile under longterm conservation tillage: a phosphorus- 31 nuclear magnetic resonance study, J. Environ. Qual., 39, 1647-1656, 2010.

Caldeira, C. L., Ciminelli, V. S. T., and Osseo-Asare, K.: The role of carbonate ions in pyrite oxidation in aqueous systems, Geochim. Cosmochim. Acta, 74, 1777-1789, https://doi.org/10.1016/j.gca.2009.12.014, 2010.

Caraco, N. F., Cole, J. J., and Likens, G. E.: Evidence for sulphatecontrolled phosphorus release from sediments of aquatic systems, Nature, 341, 316-318, https://doi.org/10.1038/341316a0, 1989.

Chorover, J. and Amistadi, M. K.: Reaction of forest floor organic matter at goethite, birnessite and smectite surfaces, Geochim. Cosmochim. Acta, 65, 95-109, https://doi.org/10.1016/S00167037(00)00511-1, 2001.

Chow-Fraser, P., Lougheed, V., Le Thiec, V., Crosbie, B., Simser, L., and Lord, J.: Long-term response of the biotic community to fluctuating water levels and changes in water quality in Cootes Paradise Marsh, a degraded coastal wetland of Lake Ontario, Wetl. Ecol. Manag., 6, 19-42, https://doi.org/10.1023/A:1008491520668, 1998.

Chun, C. L., Ochsner, U., Byappanahalli, M. N., Whitman, R. L., Tepp, W. H., Lin, G., Johnson, E. A., Peller, J., and Sadowsky, M. J.: Association of Toxin-Producing Clostridium botulinum with the Macroalga Cladophora in the Great Lakes, Environ. Sci. Technol., 47, 2587-2594, https://doi.org/10.1021/es304743m, 2013.

Cline, J. D.: Spectrophotometric determination of hydrogen sulfide in natural waters, Limnol. Oceanogr., 14, 454-458, https://doi.org/10.4319/lo.1969.14.3.0454, 1969.

Conley, D. J., Paerl, H. W., Howarth, R. W., Boesch, D. F., Seitzinger, S. P., Havens, K. E., Lancelot, C., and Likens, G. E.: ECOLOGY: Controlling Eutrophication: Nitrogen and Phosphorus, Science, 323, 1014-1015, https://doi.org/10.1126/science.1167755, 2009.

Corazza, C. and Tironi, S.: European Parliament supports ban of phosphates in consumer detergents (Press Release No. IP/11/1542), European Commission, Brussels, Belgium, 2011.

DeAngelis, K. M., Silver, W. L., Thompson, A. W., and Firestone, M. K.: Microbial communities acclimate to recurring changes in soil redox potential status, Environ. Microbiol., 12, 3137-3149, https://doi.org/10.1111/j.1462-2920.2010.02286.x, 2010.

Deng, S., Popova, I. E., Dick, L., and Dick, R.: Bench scale and microplate format assay of soil enzyme activities using spectroscopic and fluorometric approaches, Appl. Soil Ecol., 64, 84-90, https://doi.org/10.1016/j.apsoil.2012.11.002, 2013.

Doolette, A. L., Smernik, R. J., and Dougherty, W. J.: Spiking Improved Solution Phosphorus-31 Nuclear Magnetic Resonance Identification of Soil Phosphorus Compounds, Soil Sci. Soc. Am. J., 73, 919-927, https://doi.org/10.2136/sssaj2008.0192, 2009.

Dunn, C., Jones, T. G., Girard, A., and Freeman, C.: Methodologies for Extracellular Enzyme Assays from Wetland Soils, Wetlands, 34, 9-17, https://doi.org/10.1007/s13157-013-0475-0, 2013. 
Einsele, W.: Über die Beziehungen des Eisenkreislaufs zum Phosphatkreislauf im eutrophen See, Arch. Hydrobiol., 29, 664-686, 1936.

Fisher, J. B., Lick, W. J., McCall, P. L., and Robbins, J. A.: Vertical mixing of lake sediments by tubificid oligochaetes, J. Geophys. Res., 85, 3997-4006, https://doi.org/10.1029/JC085iC07p03997, 1980.

Frohne, T., Rinklebe, J., Diaz-Bone, R. A., and Du Laing, G.: Controlled variation of redox conditions in a floodplain soil: Impact on metal mobilization and biomethylation of arsenic and antimony, Geoderma, 160, 414-424, https://doi.org/10.1016/j.geoderma.2010.10.012, 2011.

Furukawa, Y., Bentley, S. J., and Lavoie, D. L.: Bioirrigation modeling in experimental benthic mesocosms, J. Mar. Res., 59, 417452, https://doi.org/10.1357/002224001762842262, 2001.

Gächter, R. and Meyer, J. S.: The role of microorganisms in mobilization and fixation of phosphorus in sediments, Hydrobiologia, 253, 103-121, https://doi.org/10.1007/BF00050731, 1993.

Gächter, R. and Müller, B.: Why the Phosphorus Retention of Lakes Does Not Necessarily Depend on the Oxygen Supply to Their Sediment Surface, Limnol. Oceanogr., 48, 929-933, https://doi.org/10.4319/lo.2003.48.2.0929, 2003.

Gächter, R., Meyer, J. S., and Mares, A.: Contribution of bacteria to release and fixation of phosphorus in lake sediments: Bacteria and $\mathrm{P}$ in sediments, Limnol. Oceanogr., 33, 1542-1558, https://doi.org/10.4319/lo.1988.33.6part2.1542, 1988.

Gardner, W. H.: Water Content, in: Methods of Soil Analysis: Physical and Mineralogical Methods, Agronomy, Soil Science Society of America, Madison, Wisconsin, 493-544, 1986.

Gehin, A., Greneche, J.-M., Tournassat, C., Brendle, J., Rancourt, D. G., and Charlet, L.: Reversible surface-sorption-induced electron-transfer oxidation of $\mathrm{Fe}(\mathrm{II})$ at reactive sites on a synthetic clay mineral, Geochim. Cosmochim. Acta, 71, 863-876, https://doi.org/10.1016/j.gca.2006.10.019, 2007.

Gerke, J.: Phosphate adsorption by humic/Fe-oxide mixtures aged at $\mathrm{pH} 4$ and 7 and by poorly ordered Fe-oxide, Geoderma, 59, 279-288, https://doi.org/10.1016/0016-7061(93)90074-U, 1993.

Gerke, J.: Humic (Organic Matter)-Al(Fe)-Phosphate Complexes: An Underestimated Phosphate Form in Soils and Source of Plant-Available Phosphate, Soil Sci., 175, 417-425, https://doi.org/10.1097/SS.0b013e3181f1b4dd, 2010.

Gorham, E. and Boyce, F. M.: Influence of Lake Surface Area and Depth Upon Thermal Stratification and the Depth of the Summer Thermocline, J. Gt. Lakes Res., 15, 233-245, https://doi.org/10.1016/S0380-1330(89)71479-9, 1989.

Grybos, M., Davranche, M., Gruau, G., Petitjean, P., and Pedrot, M.: Increasing $\mathrm{pH}$ drives organic matter solubilization from wetland soils under reducing conditions, Geoderma, 154, 13-19, https://doi.org/10.1016/j.geoderma.2009.09.001, 2009.

Hansen, J. C., Cade-Menun, B. J., and Strawn, D. G.: Phosphorus Speciation in Manure-Amended Alkaline Soils, J. Environ. Qual., 33, 1521-1527, https://doi.org/10.2134/jeq2004.1521, 2004.

Hedley, M. J., White, R. E., and Nye, P. H.: Plant-Induced changes in the rhizosphere of rape (Brassica Napus Var.Emerald) seedlings: III. Changes in L value, soil phosphate fractions and phosphatase activity, New Phytol., 91, 45-56, https://doi.org/10.1111/j.1469-8137.1982.tb03291.x, 1982.
Hölker, F., Vanni, M. J., Kuiper, J. J., Meile, C., Grossart, H.P., Stief, P., Adrian, R., Lorke, A., Dellwig, O., Brand, A., Hupfer, M., Mooij, W. M., Nützmann, G., and Lewandowski, J.: Tube-dwelling invertebrates: tiny ecosystem engineers have large effects in lake ecosystems, Ecol. Monogr., 85, 333-351, https://doi.org/10.1890/14-1160.1, 2015.

Hongve, D.: Cycling of iron, manganese, and phosphate in a meromictic lake, Limnol. Oceanogr., 42, 635-647, https://doi.org/10.4319/lo.1997.42.4.0635, 1997.

Hupfer, M., Gloess, S., and Grossart, H.: Polyphosphateaccumulating microorganisms in aquatic sediments, Aquat. Microb. Ecol., 47, 299-311, https://doi.org/10.3354/ame047299, 2007.

Hyacinthe, C. and Van Cappellen, P.: An authigenic iron phosphate phase in estuarine sediments: composition, formation and chemical reactivity, Mar. Chem., 91, 227-251, https://doi.org/10.1016/j.marchem.2004.04.006, 2004.

Jensen, D. L., Boddum, J. K., Tjell, J. C., and Christensen, T. H.: The solubility of rhodochrosite $\left(\mathrm{MnCO}_{3}\right)$ and siderite $\left(\mathrm{FeCO}_{3}\right)$ in anaerobic aquatic environments, Appl. Geochem., 17, 503511, https://doi.org/10.1016/S0883-2927(01)00118-4, 2002.

Jensen, H. S., Kristensen, P., Jeppesen, E., and Skytthe, A.: Iron:phosphorus ratio in surface sediment as an indicator of phosphate release from aerobic sediments in shallow lakes, Hydrobiologia, 235-236, 731-743, https://doi.org/10.1007/BF00026261, 1992.

Jørgensen, C., Inglett, K. S., Jensen, H. S., Reitzel, K., and Reddy, K. R.: Characterization of biogenic phosphorus in outflow water from constructed wetlands, Geoderma, 257-258, 58-66, https://doi.org/10.1016/j.geoderma.2015.01.019, 2015.

Joshi, S. R., Kukkadapu, R. K., Burdige, D. J., Bowden, M. E., Sparks, D. L., and Jaisi, D. P.: Organic Matter Remineralization Predominates Phosphorus Cycling in the Mid-Bay Sediments in the Chesapeake Bay, Environ. Sci. Technol., 49, 5887-5896, https://doi.org/10.1021/es5059617, 2015.

Kang, H. and Freeman, C.: Phosphatase and arylsulphatase activities in wetland soils: annual variation and controlling factors, Soil Biol. Biochem., 31, 449-454, https://doi.org/10.1016/S00380717(98)00150-3, 1999.

Katsev, S., Tsandev, I., L'Heureux, I., and Rancourt, D. G.: Factors controlling long-term phosphorus efflux from lake sediments: Exploratory reactive-transport modeling, Chem. Geol., 234, 127-147, https://doi.org/10.1016/j.chemgeo.2006.05.001, 2006.

Kim, D.-K., Zhang, W., Rao, Y. R., Watson, S., Mugalingam, S., Labencki, T., Dittrich, M., Morley, A., and Arhonditsis, G. B.: Improving the representation of internal nutrient recycling with phosphorus mass balance models: A case study in the Bay of Quinte, Ontario, Canada. Ecol. Model., 256, 53-68, https://doi.org/10.1016/j.ecolmodel.2013.02.017, 2013.

Kizewski, F. R., Boyle, P., Hesterberg, D., and Martin, J. D.: Mixed Anion (Phosphate/Oxalate) Bonding to Iron(III) Materials, J. Am. Chem. Soc., 132, 2301-2308, https://doi.org/10.1021/ja908807b, 2010a.

Kizewski, F. R., Hesterberg, D., and Martin, J.: Phosphate sorption to organic matter/ferrihydrite systems as affected by aging time, 19th World Congress of Soil Science, Soil Solutions for a Changing World, Brisbane, Australia, 1-6 August, 2010b. 
Klein, A. R., Baldwin, D. S., Singh, B., and Silvester, E. J.: Salinityinduced acidification in a wetland sediment through the displacement of clay-bound iron(II), Environ. Chem., 7, 413-421, https://doi.org/10.1071/EN10057, 2010.

Kortstee, G. J. J., Appeldoorn, K. J., Bonting, C. F. C., Niel, E. W. J., and Veen, H. W.: Biology of polyphosphate-accumulating bacteria involved in enhanced biological phosphorus removal, FEMS Microbiol. Rev., 15, 137-153, https://doi.org/10.1111/j.15746976.1994.tb00131.x, 1994.

Krom, M. D. and Berner, R. A.: The diagenesis of phosphorus in a nearshore marine sediment. Geochim. Cosmochim. Acta 45, 207-216, https://doi.org/10.1016/0016-7037(81)90164-2, 1981.

Lagauzère, S., Boyer, P., Stora, G., and Bonzom, J.-M.: Effects of uranium-contaminated sediments on the bioturbation activity of Chironomus riparius larvae (Insecta, Diptera) and Tubifex tubifex worms (Annelida, Tubificidae), Chemosphere, 76, 324334, https://doi.org/10.1016/j.chemosphere.2009.03.062, 2009.

Li, W., Joshi, S. R., Hou, G., Burdige, D. J., Sparks, D. L., and Jaisi, D. P.: Characterizing Phosphorus Speciation of Chesapeake Bay Sediments Using Chemical Extraction, ${ }^{31} \mathrm{P}$ NMR, and X-ray Absorption Fine Structure Spectroscopy, Environ. Sci. Technol., 49, 203-211, https://doi.org/10.1021/es504648d, 2015.

Liger, E., Charlet, L., and Van Cappellen, P.: Surface catalysis of uranium(VI) reduction by iron(II), Geochim. Cosmochim. Acta, 63, 2939-2955, https://doi.org/10.1016/S0016-7037(99)002653, 1999.

Mallin, M. A., McIver, M. R., Wells, H. A., Parsons, D. C., and Johnson, V. L.: Reversal of eutrophication following sewage treatment upgrades in the New River Estuary, North Carolina, Estuaries, 28, 750-760, https://doi.org/10.1007/BF02732912, 2005.

Manning, B. A.: Modeling Arsenate Competitive Adsorption on Kaolinite, Montmorillonite and Illite, Clays Clay Miner., 44, 609-623, https://doi.org/10.1346/CCMN.1996.0440504, 1996.

Matisoff, G. and Wang, X.: Solute transport in sediments by freshwater infaunal bioirrigators, Limnol. Oceanogr., 43, 1487-1499, https://doi.org/10.4319/lo.1998.43.7.1487, 1998.

Matisoff, G., Kaltenberg, E. M., Steely, R. L., Hummel, S. K., Seo, J., Gibbons, K. J., Bridgeman, T. B., Seo, Y., Behbahani, M., James, W. F., Johnson, L. T., Doan, P., Dittrich, M., Evans, M. A., and Chaffin, J. D.: Internal loading of phosphorus in western Lake Erie, J. Gt. Lakes Res., 42, 775-788, https://doi.org/10.1016/j.jglr.2016.04.004, 2016.

Mayer, T., Rosa, F., Mayer, R., and Charlton, M.: Relationship Between the Sediment Geochemistry and Phosphorus Fluxes in a Great Lakes Coastal Marsh, Cootes Paradise, ON, Canada, Water Air Soil Poll. Focus, 6, 495-503, https://doi.org/10.1007/s11267006-9033-6, 2006.

McCall, P. L. and Fisher, J. B.: Effects of Tubificid Oligochaetes on Physical and Chemical Properties of Lake Erie Sediments, in: Aquatic Oligochaete Biology, edited by: Brinkhurst, R. and Cook, D., Springer US, 253-317, 1980.

McLaughlin, C. and Pike, K.: Muddied Waters: The Ongoing Challenge of Sediment and Phosphorus for Hamilton Harbour Remediation (2014 Towards Safe Harbour Report), Bay Area Restoration Council, Hamilton, Ontario, 2014.

Mikutta, C. and Kretzschmar, R.: Spectroscopic Evidence for Ternary Complex Formation between Arsenate and Ferric Iron
Complexes of Humic Substances, Environ. Sci. Technol., 45, 9550-9557, https://doi.org/10.1021/es202300w, 2011.

Mortimer, C. H.: The exchange of dissolved substances between mud and water in lakes, J. Ecol., 29, 280-329, 1941.

Mortimer, C. H.: Chemical Exchanges Between Sediments and Water in the Great Lakes-Speculations on Probable Regulatory Mechanisms, Limnol. Oceanogr., 16, 387-404, https://doi.org/10.4319/lo.1971.16.2.0387, 1971.

Murphy, J. and Riley, J. P.: A modified single solution method for the determination of phosphate in natural waters, Anal. Chim. Acta, 27, 31-36, https://doi.org/10.1016/S0003-2670(00)884445,1962 .

National Water Quality Monitoring Council: 4500-P E, Phosphorus by Ascorbic Acid, Standard Methods for the Examination of Water and Wastewater, National Water Quality Monitoring Council, Washington, DC, USA, 1992.

Nikolausz, M., Kappelmeyer, U., Szekely, A., Rusznyak, A., Marialigeti, K., and Kastner, M.: Diurnal redox fluctuation and microbial activity in the rhizosphere of wetland plants, Eur. J. Soil Biol., 44, 324-333, https://doi.org/10.1016/j.ejsobi.2008.01.003, 2008.

Nürnberg, G. K.: Prediction of Phosphorus Release Rates from Total and Reductant-Soluble Phosphorus in Anoxic Lake Sediments, Can. J. Fish. Aquat. Sci., 45, 453-462, https://doi.org/10.1139/f88-054, 1988.

O'Connell, D. W., Jensen, M. M., Jakobsen, R., Thamdrup, B., Andersen, T. J., Kovacs, A., and Hansen, H. C. B.: Vivianite formation and its role in phosphorus retention in Lake Ørn, Denmark, Chem. Geol., 409, 42-53, https://doi.org/10.1016/j.chemgeo.2015.05.002, 2015.

Olsen, S. R. and Watanabe, F. S.: A Method to Determine a Phosphorus Adsorption Maximum of Soils as Measured by the Langmuir Isotherm1, Soil Sci. Soc. Am. J., 21, 144-149, https://doi.org/10.2136/sssaj1957.03615995002100020004x, 1957.

Olsen, S. R., Cole, C. V., Watanabe, F. S., and Dean, L. A.: Estimation of available phosphorus in soils by extraction with sodium bicarbonate, US Dep. Agric. Circ., 939, 1-19, 1954.

Painter, D., Hampton, L., and Simser, W. L.: Cootes Paradise Water Turbidity: Sources and Recommendations, NWRI Contribution Paper No. 91-15, Burlington, Ontario, p. 18, 1991.

Pallasser, R., Minasny, B., and McBratney, A. B.: Soil carbon determination by thermogravimetrics, PeerJ, 1, e6, https://doi.org/10.7717/peerj.6, 2013.

Paraskova, J. V., Jørgensen, C., Reitzel, K., Pettersson, J., Rydin, E., and Sjöberg, P. J. R.: Speciation of Inositol Phosphates in Lake Sediments by Ion-Exchange Chromatography Coupled with Mass Spectrometry, Inductively Coupled Plasma Atomic Emission Spectroscopy, and ${ }^{31}$ P NMR Spectroscopy, Anal. Chem., 87, 2672-2677, https://doi.org/10.1021/ac5033484, 2015.

Parkhurst, D. L. and Appelo, C. A. J.: User's guide to PHREEQC (Version 3): A computer program for speciation, batch-reaction, one-dimensional transport, and inverse geochemical calculations, US Geological Survey Reston, VA, 1999.

Parsons, C. T., Couture, R.-M., Omoregie, E. O., Bardelli, F., Greneche, J.-M., Roman-Ross, G., and Charlet, L.: The impact of oscillating redox conditions: Arsenic immobilisation in contaminated calcareous floodplain soils, Environ. Pollut., 178, 254-263, https://doi.org/10.1016/j.envpol.2013.02.028, 2013. 
Peiffer, S., Behrends, T., Hellige, K., Larese-Casanova, P., Wan, M., and Pollok, K.: Pyrite formation and mineral transformation pathways upon sulfidation of ferric hydroxides depend on mineral type and sulfide concentration, Chem. Geol., 400, 44-55, https://doi.org/10.1016/j.chemgeo.2015.01.023, 2015.

Pelegri, S. P. and Blackburn, T. H.: Effects of Tubifex tubifex (Oligochaeta: Tubificidae) on $\mathrm{N}$-mineralization in freshwater sediments, measured with isotopes, Aquat. Microb. Ecol., 9, 289-294, 1995.

Penn, M. R., Auer, M. T., Doerr, S. M., Driscoll, C. T., Brooks, C. M., and Effler, S. W.: Seasonality in phosphorus release rates from the sediments of a hypereutrophic lake under a matrix of $\mathrm{pH}$ and redox conditions, Can. J. Fish. Aquat. Sci., 57, 1033-1041, https://doi.org/10.1139/f00-035, 2000.

Phillips, G., Jackson, R., Bennett, C., and Chilvers, A.: The importance of sediment phosphorus release in the restoration of very shallow lakes (The Norfolk Broads, England) and implications for biomanipulation, Hydrobiologia, 275-276, 445-456, https://doi.org/10.1007/BF00026733, 1994.

Pomeroy, R.: Auxiliary Pretreatment by Zinc Acetate in Sulfide Analyses, Anal. Chem., 26, 571-572, https://doi.org/10.1021/ac60087a047, 1954.

Pretty, J. N., Mason, C. F., Nedwell, D. B., Hine, R. E., Leaf, S., and Dils, R.: Environmental Costs of Freshwater Eutrophication in England and Wales, Environ. Sci. Technol., 37, 201-208, https://doi.org/10.1021/es020793k, 2003.

Reddy, K. R. and DeLaune, R. D.: Biogeochemistry of wetlands: science and applications, CRC Press, Boca Raton, 2008.

Reddy, K. R., Newman, S., Osborne, T. Z., White, J. R., and Fitz, H. C.: Phosphorous Cycling in the Greater Everglades Ecosystem: Legacy Phosphorous Implications for Management and Restoration, Crit. Rev. Environ. Sci. Technol., 41, 149-186, https://doi.org/10.1080/10643389.2010.530932, 2011.

Reitzel, K., Ahlgren, J., DeBrabandere, H., Waldebäck, M., Gogoll, A., Tranvik, L., and Rydin, E.: Degradation rates of organic phosphorus in lake sediment, Biogeochemistry, 82, 15-28, https://doi.org/10.1007/s10533-006-9049-z, 2007.

Rezanezhad, F., Couture, R.-M., Kovac, R., O'Connell, D., and Van Cappellen, P.: Water table fluctuations and soil biogeochemistry: An experimental approach using an automated soil column system, J. Hydrol., 509, 245-256, https://doi.org/10.1016/j.jhydrol.2013.11.036, 2014.

Rickard, D. and Morse, J. W.: Acid volatile sulfide (AVS), Mar. Chem., 97, 141-197, https://doi.org/10.1016/j.marchem.2005.08.004, 2005.

Routledge, I.: City of Hamilton: King Street (Dundas) Wastewater Treatment Plant, 2011 Annual Report (Annual Report No. Works Number 120001372), The City of Hamilton, Environment and Sustainable Infrastructure Division, Hamilton, Ontario, 2012.

Ruttenberg, K. C.: Development of a sequential extraction method for different forms of phosphorus in marine sediments, Limnol. Oceanogr., 37, 1460-1482, https://doi.org/10.4319/lo.1992.37.7.1460, 1992.

Sannigrahi, P. and Ingall, E.: Polyphosphates as a source of enhanced $\mathrm{P}$ fluxes in marine sediments overlain by anoxic waters: Evidence from ${ }^{31} \mathrm{P}$ NMR, Geochem. Trans., 6, 52, https://doi.org/10.1063/1.1946447, 2005.
Semkin, R. G., McLarty, A. W., and Craig, D.: A water quality study of Cootes Paradise, Ontario Ministry of Environment, West Central Region, Toronto, Ontario, 1976.

Sharma, P., Ofner, J., and Kappler, A.: Formation of Binary and Ternary Colloids and Dissolved Complexes of Organic Matter, Fe and As, Environ. Sci. Technol., 44, 4479-4485, https://doi.org/10.1021/es100066s, 2010.

Sharpley, A. N., Chapra, S. C., Wedepohl, R., Sims, J. T., Daniel, T. C., and Reddy, K. R.: Managing Agricultural Phosphorus for Protection of Surface Waters: Issues and Options, J. Environ. Qual., 23, 437-451, https://doi.org/10.2134/jeq1994.00472425002300030006x, 1994.

Sibanda, H. M. and Young, S. D.: Competitive adsorption of humus acids and phosphate on goethite, gibbsite and two tropical soils, J. Soil Sci., 37, 197-204, https://doi.org/10.1111/j.13652389.1986.tb00020.x, 1986.

Sirová, D., Rejmánková, E., Carlson, E., and Vrba, J.: Current standard assays using artificial substrates overestimate phosphodiesterase activity, Soil Biol. Biochem., 56, 75-79, https://doi.org/10.1016/j.soilbio.2012.02.008, 2013.

Smith, V. H. and Schindler, D. W.: Eutrophication science: where do we go from here?, Trends Ecol. Evol., 24, 201-207, https://doi.org/10.1016/j.tree.2008.11.009, 2009.

Søndergaard, M., Jensen, J. P., and Jeppesen, E.: Role of sediment and internal loading of phosphorus in shallow lakes, Hydrobiologia, 506-509, 135-145, https://doi.org/10.1023/B:HYDR.0000008611.12704.dd, 2003.

Song, K.-Y., Zoh, K.-D., and Kang, H.: Release of phosphate in a wetland by changes in hydrological regime, Sci. Total Environ., 380, 13-18, https://doi.org/10.1016/j.scitotenv.2006.11.035, 2007.

Stookey, L. L.: Ferrozine - a new spectrophotometric reagent for iron, Anal. Chem., 42, 779-781, https://doi.org/10.1021/ac60289a016, 1970.

Stumm, W. and Morgan, J. J.: Aquatic Chemistry, 3rd Edn., John Wiley \& Sons, New York, 1996.

Theysmeyer, T., Smith, T., and Simser, L.: West Pond 1999 Study, Royal Botanical Gardens, Science Department, 1999.

Thibault, P.-J., Rancourt, D. G., Evans, R. J., and Dutrizac, J. E.: Mineralogical confirmation of a near-P : $\mathrm{Fe}=1: 2$ limiting stoichiometric ratio in colloidal P-bearing ferrihydrite-like hydrous ferric oxide, Geochim. Cosmochim. Acta, 73, 364-376, https://doi.org/10.1016/j.gca.2008.10.031, 2009.

Thompson, A., Chadwick, O. A., Rancourt, D. G., and Chorover, J.: Iron-oxide crystallinity increases during soil redox oscillations, Geochim. Cosmochim. Acta, 70, 1710-1727, https://doi.org/10.1016/j.gca.2005.12.005, 2006.

Turner, B. L., Cade-Menun, B. J., and Westermann, D. T.: Organic phosphorus composition and potential bioavailability in semiarid arable soils of the Western United States, Soil Sci. Soc. Am. J., 67, 1168-1179, 2003a.

Turner, B. L., Mahieu, N., and Condron, L.: Phosphorus-31 Nuclear Magnetic Resonance Spectral Assignments of Phosphorus Compounds in Soil NaOH-EDTA Extracts, Soil Sci. Soc. Am. J., 67, 497-510, https://doi.org/10.2136/sssaj2003.4970, 2003 b.

US EPA: Field Sampling Guidance Document: Sediment Sampling (No. \#1215), US Environmental Protection Agency, Region 9 Laboratory, Richmond California, September 1999. 
Vetter, Y. A., Deming, J. W., Jumars, P. A., and Krieger-Brockett, B. B.: A Predictive Model of Bacterial Foraging by Means of Freely Released Extracellular Enzymes, Microb. Ecol., 36, 7592, https://doi.org/10.1007/s002489900095, 1998.

Viollier, E., Inglett, P., Hunter, K., Roychoudhury, A., and Van Cappellen, P.: The ferrozine method revisited: $\mathrm{Fe}(\mathrm{II}) / \mathrm{Fe}(\mathrm{III}) \mathrm{de}-$ termination in natural waters, Appl. Geochem., 15, 785-790, https://doi.org/10.1016/S0883-2927(99)00097-9, 2000.

Weishaar, J. L., Aiken, G. R., Bergamaschi, B. A., Fram, M. S., Fujii, R., and Mopper, K.: Evaluation of Specific Ultraviolet Absorbance as an Indicator of the Chemical Composition and Reactivity of Dissolved Organic Carbon, Environ. Sci. Technol., 37, 4702-4708, https://doi.org/10.1021/es030360x, 2003.
Wentzel, M. C., Lötter, L. H., Ekama, G. A., Loewenthal, R. E., and Marais, G. v. R.: Evaluation of Biochemical Models for Biological Excess Phosphorus Removal, Water Sci. Technol., 23, 567-576, 1991.

Yamamoto-Ikemoto, R., Matsui, S., and Komori, T.: Ecological interactions among denitrification, poly-P accumulation, sulfate reduction, and filamentous sulfur bacteria in activated sludge, Water Sci. Technol., 30, 201-210, 1994. 